\title{
LA FORMACIÓN DE UN PATRIMONIO NOBILIARIO EN EL SEISCIENTOS VALENCIANO. EL PRIMER MARQUÉS DE RAFAL*
}

\section{Por David BERNABÉ GIL}

Universidad de Alicante

\section{Introducción}

Uno de los métodos más eficaces - pero no menos laborioso- de que dispone el historiador en su intento de aprehender el pasado es posiblemente el estudio de los personajes más representativos en relación al problema que se pretende abordar o, incluso, de aquellos que, aún habiendo permanecido en un relativo anonimato, pueden caracterizar con su ejemplo a un colectivo más amplio. Tal procedimiento no está, sin embargo, exento de riesgos y a menudo suele acechar la tentación de generalizar a partir de casos aislados de difícil extrapolación. Pero una vez evitado el peligro quizá pueda llegarse a constatar que también lo excepcional, por minoritario, posee un valor explicativo propio, constituyendo un buen indicador de los mecanismos actuantes en el desarrollo de un proceso histórico determinado ${ }^{(1)}$.

Valga, pues, esta mera observación preliminar para introducirnos en el tema del presente trabajo y plantear algunos de sus objetivos y dificultades.

Se tratará aquí, fundamentalmente, de analizar la actividad desarrollada por D. Jerónimo Rocamora, artífice del valioso patrimonio que consagraría a la casa de Rafal como una de las más poderosas e influyentes familias nobiliarias del sur valenciano, y cuya vida transcurrió a caballo de los siglos XVI y XVII. En 1626, el consejero Castellvi lo definía como «cavallero muy calificado y de los mas principales deste Reyno y de grandissima hazienda, la mayor que ay en aquella parte de Orihuela»(2).

\footnotetext{
* Este trabajo se inscribe dentro de la problemática tratada en la tesis doctoral que
} vengo realizando sobre El Bajo Segura en el siglo XVII. 
Pero a diferencia de uno de los sucesores al título, cuya decisiva y siempre controvertida participación en la Guerra de Sucesión le haría acreedor de una mayor atención historiográfica ${ }^{(3)}, \mathrm{D}$. Jerónimo no llegaría a destacar de modo tan visible en la esfera política del momento; circunstancia que ha condicionado sin duda el que su labor haya permanecido insuficientemente valorada ${ }^{(4)}$. Sin embargo, a poco que se indague sobre el entorno en que desarrolló su existencia, su nombre surgirá una y otra vez vinculado a las más diversas facetas de actividad económica, configurando una personalidad cuyo protagonismo resultará ya difícil ignorar.

El interés que despierta su variado ámbito de actuación y la interrelación existente entre todos sus elementos ha de justificarse no sólo por lo que pueda representar como paradigma de una determinada opción nobiliaria poco común, sino, además, porque revela las posibilidades que ofrecía la difícil coyuntura del momento a quienes eran capaces o estaban en condiciones de aprovechar los mecanismos disponibles para su superación. En este sentido, su obra puede contribuir a abrir nuevas perspectivas para calibrar el alcance de la crisis y las transformaciones que, con ella, se estaban produciendo en la sociedad y la economía de las comarcas meridionales del Reino ${ }^{(5)}$.

He de advertir, por otra parte, que tanto o más que los logros alcanzados por el protagonista de esta historia, interesaba indagar los procedimientos de que se sirvió para su consecución e intentar explicar su lógica interna. El conocimiento de las circunstancias que habrían de concurrir en cada caso se revelaba, de este modo, como uno de los objetivos prioritarios de la investigación, dado su gran valor explicativo. Pero, obviamente, ello no podía agotar todo intento de interpretación, por lo que, en alguna ocasión - como ocurrirá con el análisis de su actividad señorial - ha sido necesario ponderar ciertos elementos solo aparentemente ajenos al propósito inicial e incluso proceder con mayor cautela de la que hubiera sido deseable a la hora de establecer conclusiones.

Probablemente estas advertencias no hubieran tenido cabida aquí de haber contado con fuentes más homogéneas y explícitas sobre el contenido de la investigación, que hubieran facilitado sin duda su desarrollo y ahorrado incontables horas de infructuosa búsqueda.

Decenas de libros de protocolos notariales ${ }^{(6)}$ y centenares de expedientes de la sección de Procesos del Archivo Histórico de Orihuela, actualmente sin inventariar ${ }^{(7)}$, han tenido que ser revisados en pos del dato concreto que arrojara alguna luz sobre cuestiones que apenas han dejado rastro documental alguno. No menos imprescindible ha sido tener que rastrear en el Archivo Municipal de Orihuela noticias aisladas que hicieran referencia a nuestro hombre y contribuyeran a precisar el tipo de relaciones que mantenía con la comunidad, siendo, por otra parte, escasísimas las que he podido localizar en otros archivos de ámbito más general, como el del Reino de Valencia y el de la Corona de Aragón(8).

En suma, el carácter extraordinariamente disperso y desigual de la documentación manejada ha condicionado en buena medida el alcance y el fiel cumplimiento de los objetivos propuestos en un principio, dejando abierto el tema a nuevas aportaciones que clarifiquen en un futuro determinadas cuestiones insuficientemente documentadas. Con todo, las páginas que siguen a continuación in- 
tentarán mostrar abundantes elementos de juicio para comprender las líneas maestras de una determinada actitud nobiliaria y, por ende, de los problemas que aquejaban a una sociedad.

\subsection{Datos biográficos}

El 9 de abril de 1571, en el seno de una familia perteneciente a la pequeña nobleza oriolana, de honda raigambre local, tenía lugar el nacimiento del primer hijo varón, que posteriormente sería bautizado con el nombre de Jerónimo. Su padre, D. Jaime Rocamora y López de Barea, descendía de un antiguo linaje de caballeros que habían acompañado al rey Jaime en la conquista de la ciudad, mientras que su madre, D. ${ }^{a}$ Ana Thomas y Vázquez, era natural de Murcia ${ }^{(9)}$. Fruto primero de este enlace, el joven Jerónimo habría de suceder muy pronto, en calidad de primogénito en la titularidad de buena parte del patrimonio familiar, previamente vinculado por su progenitor días antes de morir, en $1588^{(10)}$.

Unos años más tarde, en 1593, nuestro hombre contraía su primer matrimonio con $\mathrm{D} .^{a}$ Isabel Molins y Rosell, descendiente también de la antigua nobleza oriolana, procreando con ella dos hijos varones - Nicolás y Alonso- y cuatro hembras --Angela, Isabel, Ana y María(11).

Cuando aún se hallaba en plena madurez, el temprano fallecimiento de su esposa obligaría a plantearse la conveniencia de un nuevo enlace. Aunque la sucesión pudiera parecer asegurada, la perspectiva de incrementar un patrimonio personal aún no excesivamente cuantioso mediante la incorporación de una nueva dote hubo de resultar decisiva. Por lo demás, era bastante común entre los miembros de la nobleza que enviudaban prematuramente buscar un nuevo consorte $^{(12)}$. Y así lo haría D. Jerónimo a sus 40 años de edad, eligiendo para esta ocasión a una doncella con bastantes probabilidades de llegar a ser en un futuro una rica heredera.

En 1611, D. $^{a}$ María García de Lasa se convertía en su segunda esposa ${ }^{(13)}$. Su juventud permitiría, además, incrementar la descendencia con cinco miembros más: Gaspar, Catalina, Jaime, Juan e Inés ${ }^{(14)}$.

El 13 de agosto de 1639 , a la edad de 68 años, fallecía D. Jerónimo ${ }^{(15)}$. Dejaba tras de sí once hijos y una fortuna jamás conocida en el Bajo Segura.

Más adelante, a medida que nos vayamos introduciendo en el tema, se añadirán otros datos de interés biográfico, pero quizá no esté de más adelantar ahora un rasgo de su personalidad que acompañará su quehacer hasta el final de sus días y que posiblemente ayudará a comprender el éxito alcanzado. D. Jerónimo fue un hombre que mostró especial apego a la tierra que le vio nacer; y no solamente por una mera relación sentimental. Se trataba ante todo de evitar cualquier ausencia prolongada que pudiera apartarle del directo seguimiento de cuanto en ella acontecía.

Ciertamente, en más de una ocasión se haría poco menos que imprescindible su presencia en la sede de tribunales foráneos donde se dilucidaban ciertos asuntos conflictivos ${ }^{(16)}$ o allí hasta donde alcanzaban las ramificaciones de sus negocios, pero un buen séquito de procuradores con suficientes poderes le ahorraba frecuentemente esta misión ${ }^{(17)}$. Ello no contradice, antes al contrario, su firme 
propósito de dirigir y gestionar personalmente sus propios asuntos, en su gran mayoría estrechamente vinculados al Bajo Segura y zonas limítrofes. Su extraordinaria vocación y dedicación por cualquier tipo de actividad que pudiese ser rentable le llevaría a prescindir de administrador alguno, asumiendo él directamente toda función que conllevara la más mínima responsabilidad. Quizá muy pocos como él conocían realmente el mundo en que vivían y disponían de la necesaria intuición para buscar y encontrar la fortuna. En consecuencia, el calificativo de absentista no tendrá cabida entre los rasgos que definen su personalidad ${ }^{(18)}$.

\section{La fortuna de D. Jerónimo}

A partir de los datos disponibles es posible conocer de forma bastante aproximada el patrimonio acumulado por Rocamora, así como los medios empleados para su consecución, al menos en la segunda etapa de su vida. Aunque no ha sido posible constatar la exacta magnitud de los bienes que sirvieron de base a su posterior ampliación, es de sospechar que ni siquiera llegaron a alcanzar, de hecho, los expresados en el vínculo formado por su padre. Al comparar los que integraban dicho patrimonio familiar con los que realmente permanecían en poder de $\mathrm{D}$. Jerónimo en 1611, se echa en falta una propiedad, sin que pueda añadir nada más acerca de su destino. Veamos, no obstante, cuáles eran las partidas constitutivas del vínculo formado en 1588 por D. Jaime ${ }^{(19)}$ :

\section{CUADRO I}

\begin{tabular}{|c|c|c|}
\hline \multicolumn{3}{|c|}{ Patrimonio heredado por D. Jerónimo Rocamora } \\
\hline Heredad de Benferri & 5.000 tahúllas & campo \\
\hline Heredad de La Boguera $(20)$ & 375 tahúllas & huerta \\
\hline Heredad del Cabesol ......... & 413 tahúllas & huerta \\
\hline $\begin{array}{l}2 \text { parcelas de moreral .......... } \\
1 \text { casa en Orihuela }\end{array}$ & 52 tahúllas & huerta \\
\hline 1 molino harinero & & \\
\hline & & \\
\hline
\end{tabular}

Fuente: Vínculo instituido por D. Jaime Rocamora, 1588.

A excepción de la heredad del Cabesol, el resto de las propiedades permanecerían en manos de $\mathrm{D}$. Jerónimo como hereu del vínculo paterno, aunque es posible que también recibiera otros bienes muebles o de cualquier condición por línea materna ${ }^{(21)}$. En todo caso, ha de concluirse que, con ser importante, su patrimonio original no resultaba excesivo en relación a los detentados por otros miembros de la nobleza del entorno, particularmente aquellos que ostentaban condición señorial.

Sin embargo, en el transcurso de los años anteriores a 1611 , su riqueza se vería ya notablemente incrementada, valorándose en 67.421 libras los bienes libres aportados a su segundo matrimonio - celebrado ese año-, además de la herencia ya mencionada ${ }^{(2)}$. El desglose de las partidas que integraan las recientes adquisiciones revela ya claramente cuales habían sido los campos de inversión pre- 
feridos por nuestro hombre antes de cumplir los cuarenta años de edad, en lo que he de calificar como primera etapa de su vida.

\section{CUADRO II}

Bienes libres de D. Jerónimo en 1611 4 censales que le responde la ciudad de Orihuela .... 8 censales en propiedad

7.800 libras

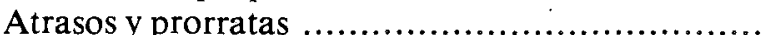

Obligaciones

14.016 libras

4.259 libras

Préstamos

1.253 libras

Otras deudas por cobrar

2.030 libras

Yeguada

6.627 libras

Vaquería

6.216 libras

100 machos cabríos

3.638 libras

Ganado lanar

287 libras

Dinero en efectivo

6.550 libras

Vellón adulterado entregado en Orihuela

2.060 libras

Muebles y joyas ....

2.640 libras

2 esclavas y 1 esclavo

2.000 libras

390 libras

Existencias en trigo y vino

430 libras

118 tahúllas de huerta

7.921 libras

Fuente: ACO: Protocólos de Luis Angulo, cap. matr. de 11-IV-1611

Si en estas fechas, su patrimonio ya había experimentado una notable diversificación, en lo sucesivo su atención se dirigirá de un modo especial hacia otros ámbitos de actuación anteriormente más desasistidos. Tal y como revela el inventario de sus bienes realizado al poco tiempo de su muerte por su viuda y usufructaria, la fortuna de $\mathrm{D}$. Jerónimo había experimentado un crecimiento tan variado como espectacular. Incluso a pesar de las continuas detracciones a que hubo de hacer frente para dotar convenientemente a su numerosa prole de cara a sus respectivos matrimonios. He aquí, pues, el balance final de los títulos y bienes que había conseguido acumular al final de sus días, una vez descontadas algunas partidas ya transmitidas a sus hijos.

A todo ello habría que añadir, además, el vínculo de Benferri -descrito anteriormente - con sus mejoras, consistentes fundamentalmente en su transformación en lugar y señorío con jurisdicción alfonsina, amén de otras incorporaciones anexas, como se explicará más adelante.

Aunque a primera vista pudiera constituir motivo de sorpresa, la nueva orientación que parece haber presidido su actividad en esta segunda etapa no sería ajena - como tampoco lo fue la anterior - a la coyuntura recientemente desatada en todo el Reino y cuyas inmediatas consecuencias pronto comenzarían a vislumbrarse en el marco comarcal donde habría de desplegar su innegable vocación empresarial. La diversidad de direcciones en que volcó su extraordinaria capacidad para el mundo de los negocios aconseja, por tanto, que nos detengamos en algunas de sus facetas más interesantes. 


\section{CUADRO III}

Principales propiedades de D. Jerónimo en $1639^{(23)}$

Marquesado de Rafal

Baronía de Puebla de Rocamora

La Majada Vieja

Heredad de Tell

Heredad La Era Alta

Heredad en la Puerta de Murcia

9 parcelas de moreral

1 cañada en Salinas

2.000 tahúllas almarjal

330 tahúllas huerta

200 tahúllas huerta

65 tahúllas huerta

178 tahúllas huerta

? campo

Créditos contra la ciudad de Orihuela, por valor de

25.000 libras

Préstamos «a cambi» por valor de

17.800 libras

502 obligaciones por valor de

33.034 libras

4 censales en propiedad por valor de

6.474 libras

Vaquería

306 cabezas

Yeguada

160 cabezas

Ovejas

1.050 cabezas

Borregos

645 cabezas

Cerdos

163 cabezas

Fuente: ACO: Protocolos de Ginés Martínez, inventario de 7-XI-1639

\section{Actividad crediticia}

Dadas las crecientes dificultades para rentabilizar otras formas de inversión, el negocio censalista seguía representando en el reino valenciano una de las modalidades más comunes de emplear los capitales disponibles, en el tránsito de los siglos XVI al XVII ${ }^{(24)}$. En el Bajo Segura se añadía, además, una importante razón para decidir hacia este tipo de empréstitos; la vigencia hasta 1622, en que se decretó su reducción general al $5 \%$, de unos tipos de interés excesivamente elevados en comparación con el resto del territorio valenciano; alcanzando a veces las pensiones hasta el $10 \%$ del valor del capital ${ }^{(25)}$. No ha de extrañar, por tanto, que destacadas instituciones con disponibilidades financieras y necesidad de rentas fijas - como el Colegio de Predicadores, por ejemplo- acudieran con relativa frecuencia al censal como uno de los medios más seguros para garantizar unos ingresos anuales ${ }^{(2)}$. La actividad crediticia podia resultar asi una importante fuente de rentas cuando las circunstancias le eran favorables en relación a otras posibles alternativas.

Estas condiciones cambiaron, sin embargo, a tenor de la política desarrollada por la corona en los años siguientes a la expulsión de los moriscos ${ }^{(27)}$. En adelante, los efectos de una legislación orientada a compensar las pérdidas sufridas por los deudores acabarían desanimando las nuevas inversiones censalistas. Sobre todo, para los sectores más emprendedores, cuyas expectativas de ganancias 
habrian de dirigirse por otros derroteros. Aunque la validez de esta afirmación precise aún de estudios más completos sobre el particular, en buena lógica esa debiera haber sido la tendencia general(28). No hay que olvidar, sin embargo, el factor demanda y, además, la virtualidad del censal, en tanto que propiedad, para actuar como soporte económico con que hacer frente a los derechos de herencia.

Por lo que respecta al personaje que aquí nos interesa, los datos que enmarcan su trayectoria financiera aportan interesantes revelaciones acerca de su habilidad en el terreno crediticio; constituyendo un ejemplo de primera magnitud para comprender los recursos de que disponían los elementos más dinámicos del momento y el modo de encauzarlos para lograr sus objetivos. Si comparamos los datos recogidos en el inventario de sus bienes realizado en 1611 con el de 1639 podrán extraerse unas primeras conclusiones:

1.-El crédito total, si bien aumentó considerablemente, no lo hizo en todas sus modalidades por igual. En cualquier caso representó una inversión de especial predilección por parte de $\mathrm{D}$. Jerónimo.

2.-Los censales, que interesaron vivamente en un principio, disminuyeron tanto en capital como en número de censatarios. Esto indica, evidentemente, que gran parte de ellos habían sido redimidos o enajenados en el transcurso de estos años.

3.-Atendiendo a la personalidad de los deudores, en 1639 sólo figuran dos nuevos censatarios que no lo eran anteriormente; pero, en conjunto, únicamente representan 400 libras de principal. Cifra, por tanto, insignificante en relación al total y que parece confirmar el escaso aprecio que debió mostrar D. Jerónimo, en su segunda etapa, hacia este tipo de rentas. Más adelante matizaré este supuesto.

4.-El crédito a corto plazo, materializado en obligaciones y préstamos a cambio, experimentó un notable incremento, configurándose como la modalidad preferida en este terreno. Tanto más si se tiene en cuenta que las cantidades referidas han de considerarse a título meramente indicativo, puesto que al tratarse de crédito amortizable a corto plazo - a diferencia de los censales- reflejan sólo aquellos créditos que permanecían sin cobrar en 1639. Con todo, muchas de las 502 obligaciones registradas habían sido constituidas en 1611 y años posteriores, lo que indica las dificultades para su liquidación.

5.--Aunque los créditos sobre la ciudad de Orihuela abarcaban deudas de todo tipo, siendo imposible delimitar con exactitud su composición real, las cotas alcanzadas reflejan la creciente dependencia financiera de la institución municipal con respecto a $\mathrm{D}$. Jerónimo. También este aspecto será tratado más detenidamente.

En consecuencia, los hechos anteriormente indicados sugieren que el préstamo a corto plazo iría ocupando un lugar cada vez más destacado en las operaciones crediticias de nuestro hombre en detrimento del censal, cuya viabilidad como fuente de beneficios quedaría paulatinamente marginada. En gran medida, este cambio de orientación ha de explicarse por el desánimo que debió cundir entre los acreedores censalistas a la vista de las medidas adoptadas por la corona sobre los tipos de interés, pero también por las ventajas que suponía para un hombre con mentalidad emprendedora - y no meramente rentista - la posibilidad de recobrar a breve plazo la cantidad originariamente aprontada sin tener que renun- 
ciar por ello a los intereses devengados. Por otra parte, la venta a crédito permitía poner en el mercado un ingente volumen de mercancías difícilmente comercializables mediante el pago al contado, dada la penuria monetaria de los sectores sociales que solían adquirirlas. La nueva tendencia inversora adoptada en la segunda etapa reflejaría, por tanto, una inmejorable adaptación a las condiciones del momento.

Pero el simple balance realizado hasta el momento no capta, sin embargo, la complejidad de las operaciones desarrolladas en el terreno crediticio. Un examen detenido de la documentación consultada revelará las motivaciones y resultados obtenidos de su comportamiento, reflejo perfecto de las posibilidades que ofrecía la dificil coyuntura de estos años.

\subsection{Obligaciones}

El análisis de una muestra suficientemente representativa de esta modalidad de crédito y las propias indicaciones que suelen aparecer en el inventario de 1639 arroja alguna luz sobre la función que desempeñó en las relaciones que D. Jerónimo sostuvo con su entorno ${ }^{(29)}$. Aunque no siempre aparece especificado el motivo concreto de su constitución, en su mayor parte tratábanse de formas de pago aplazado merced a la intensa actividad comercial desarrollada y la imposibilidad real de hacer efectiva en el acto el precio de la transacción. Mediante la obligación por venta a crédito, el comprador reconocía haber recibido la mercancia, quedando obligado a su pago en un futuro cercano que, a veces, solía ser puntualmente fijado. Eran objeto frecuente de compra-venta con obligación el ganado -particularmente los animales de labor-, pieles y lanas, determinados productos agrarios, etc.

En otras ocasiones, sin embargo, la obligación asumía la forma de un préstamo en efectivo realizado «de boca per a ferlos plaer e bona obra» ${ }^{(30)}$. Por último, también se contrajeron obligaciones por alquileres, arrendamientos y cualquier otro tipo de transacción -en la práctica, similar a la venta a crédito-o bien como reconocimiento de deudas atrasadas.

En cualquier caso, importa sobre todo conocer si la obligación encubría realmente un interés o un beneficio de otro tipo para D. Jerónimo, ya que formalmente no solían aparecer en las escrituras.

Tal y como repetidamente ha sido señalado

«En el caso de las ventas a crédito se puede decir que el interés va incluido en la necesidad de vender y por supuesto en la diferencia de precio existente entre el pago al contado y el pago a corto, medio o largo plazo. Además en todos los planteamientos se goza de la posibilidad de utilizar el mecanismo de la ejecución para quedarse con los bienes del deudor en el caso, más que probable por imposibilidad natural, de que éste no cumpliese el compromiso estipulado en el contrato $)^{(31)}$.

O bien, como ha indicado Bennassar, para el caso del «crédito amistoso»

«los escritos de los escribanos pretenden que se trata para el prestamista de "hacer honra y buena obra" para su prestatario. Por 
supuesto no debemos creerlo. Philippe Wolff, Paul Ourliac y Jean de Malfosse han demostrado con suficiente claridad que se trataba de préstamos camuflados para eludir las prohibiciones canónicas»(32).

Además de estas consideraciones, en nuestro caso también ha sido posible detectar algunos elementos que evidencian las ventajas de este mecanismo de crédito; como, por ejemplo, la adquisición gratuita de tierras por parte de D. Jerónimo ${ }^{(33)}$ o el cobro en especie - fundamentalmente en seda - a un precio inferior ${ }^{(34)}$ por impago de sus deudores, sin necesidad de recurrir a acciones judiciales. Lo que no implica, por otra parte, que en determinadas ocasiones hubiera de utilizar la vía ejecutiva. Otras veces, cuando el plazo de la obligación había transcurrido sin haber sido liquidada, no era extraño conceder una prórroga aplicando ahora intereses claramente definidos en sustituión de la ejecución. Así, por ejemplo, el 22 de noviembre de 1630, Jaime Ortiz, caballero de Orihuela, ante la imposibilidad de hacer efectivas las 720 libras que debía a D. Jerónimo, obtuvo una prórroga hasta el 2 de agosto de 1631 para su pago «ensemps ab lo interes mercantil contador per fires de Medina del Campo ratione lucri cessantis et damni emergentis $)^{(35)}$.

Parece evidente, por tanto, la función asumida por la obligación en el mercado de créditos, como instrumento que permitía la generación de intereses sin vulnerar la legalidad. Esta forma de usura encubierta proporcionaba además un cierto tipo de control económico del acreedor sobre el deudor, cuya capacidad para disponer libremente de sus bienes podía quedar sensiblemente mermada.

No ha de olvidarse, sin embargo, el riesgo inherente a todo crédito formalizado sin garantía hipotecaria, cual era el caso de la obligación: la posibilidad de no recobrar jamás el capital por insolvencia manifiesta o desaparición física del deudor. Y, efectivamente, fueron varios los casos en que esto ocurrió( ${ }^{(36)}$. Es por ello que Rocamora también utilizara con cierta frecuencia sus activos en obligaciones como medio de pago, bien en sus transacciones comerciales ${ }^{(37)}$ bien en sus transmisiones hereditarias ${ }^{(38)}$.

\subsection{Préstamos «a cambio»}

La formalización legal del crédito con interés quedaba reflejada, sin embargo, a través de este instrumento, generalmente reservado para operaciones financieras más importantes. También aquí destacaría D. Jerónimo, aunque es difícil conocer en qué medida a partir de la documentación consultada, por lo que he de remitirme, a título indicativo, a los datos que ofrece el inventario de $1639^{\left({ }^{(39}\right)}$ y a los que se aducirán más adelante al tratar de sus relaciones con la ciudad de Orihuela. No se agota con ello, en modo alguno, el total de operaciones efectuadas $y$, de hecho, podrían aducirse otros ejemplos ${ }^{(40)}$, referentes incluso a pagos realizados por sus agentes en Madrid u otras plazas peninsulares ${ }^{(41)}$. En cuanto a los intereses que estos créditos devengaban, solian estipularse «conforme le guany de les fires de Medina del Campo... en la forma e manera que semblants deudors que han pres a cambi es acostumat» ${ }^{(42)}$. Según Casey, en 1619 una pragmática redujo los tipos al 10\%, pero anteriormente podían alcanzar hasta el 19\%, situándose en cualquier caso por encima del censal ${ }^{(43)}$. 


\subsection{Censales}

El mecanismo del censal, si no exahustivamente conocido, ya ha sido descrito varias veces ${ }^{(4)}$, por lo que me abtendré aquí de entrar en consideraciones sobre su funcionamiento, para prestar mayor atención al caso concreto que nos ocupa. Por el momento, conviene señalar la preferencia de D. Jerónimo por constituir este tipo de empréstitos sobre colectivos y comunidades.

Ya en 1611 , el 79,3\% de la propiedad censalista global en su haber era respondida por cuatro de ellos; la ciudad de Orihuela (7.800 libras), los regantes del Azud de Alfeytami en Almoradí (7.000 libras), el lugar de Redován (1.500 libras) y la villa de Elche (1.000 libras). El hecho de que optara por estas corporaciones a la hora de decidir su ámbito de inversión crediticia no obedece a una mera cuestión de azar, como lo demuestran sus propias palabras, en el encargo contenido en su testamento de 1626 :

«que lo esmer y carregament de censals sien comprant censals que faran la Ciutat de Oriola o la de València o per a fi y efecte de redimir-ne altres que les dites ciutats faran ab pacte de succehir en lo dret de prioritat e possioritat»(45).

La desastrosa situación financiera por la que ambos municipios atravesaban ${ }^{(46)}$ no habría de constituir obstáculo alguno para su decisión, antes al contrario. Tal actitud debía responder, si no a una meditada previsión, sí al menos a una recóndita pero razonable intuición que los acontecimientos posteriores se encargarían de confirmar.

Desde finales del Quinientos, el cobro puntual de las pensiones de censales se iba erigiendo en uno de los graves problemas con que hubieron de enfrentarse los acreedores valencianos; situación que empeoró definitivamente después de 1609 . No sólo era una gran parte de la nobleza -y, por extensión, las aljamas moriscas o los lugares de cristianos viejos sometidos a su dominio- los que se mostraban incapaces de afrontar los compromisos contraídos con los acreedores. Ciertos municipios de realengo y otros colectivos tampoco pudieron escapar a un proceso de creciente endeudamiento y de insolvencia progresiva, paralelo a la crisis agraria y demográfica del momento ${ }^{(47)}$.

El propio D. Jerónimo no dejaría de verse afectado por esta situación, parece ser que bastante generalizada, y en 1611 valoraba en 4.259 libras los atrasos que le adeudaban por sus censales; lo que representaba el $20 \%$ del principal o, si se prefiere, una cantidad casi tres veces superior a los intereses que devengaban. Casi con toda seguridad, la mayor parte debia corresponder a las comunidades que respondían los censales más elevados, como la ciudad de Orihuela y los regantes del Azud de Alfeytamí.

Pero este problema no parece que le preocupara en demasía, al menos en un primer momento y siempre que los atrasos no alcanzaran cotas excesivas. Lo importante - debió pensar- era entrar en contacto con colectivos de este tipo. A la superior garantía hipotecaria de los bienes que respaldaban los créditos contraídos por comunidades en relación a los de titularidad particular, habría que añadir un segundo elemento a su favor: la posibilidad de llegar a recibir tratos de favor e incluso de presionar, llegando el momento, en sus relaciones con dichos co- 
lectivos, sobre todo cuando la insolvencia económica de estos y el previsible temor a ejecuciones y embargos por impago ponía en sus manos un poderoso instrumento de coacción negociadora. Que Rocamora supo valerse de las ventajas que la insolvencia - pero también la despreocupación administrativa-ajena podía proporcionarle, utilizando diversos mecanismos, nos lo revela el análisis de los dos casos reseñados a continuación.

\subsection{Relación financiera con los regantes de Alfeytamí}

El censal de 7.000 libras que recaía sobre los regantes de Alfeytamí había sido otorgado por dicha comunidad en 1610 a favor de D. Jerónimo, con una pensión de 18 dineros por libra, esto es, al 7,5\%(48). A cambio de ello, éste se obligaba a redimir o reconocer un total de 23 censales que respondía el Azud a diversos particulares por un valor global teóricamente equivalente. En principio, pues, parecía tratarse de una mera operación de intercambio realizada con el fin de facilitar el pago de las deudas del Azud al quedar absorbidas todas ellas en un solo censal y evitar así su dispersión. Posteriormente, los regantes denunciarían la existencia de fraude alegando que 6 de los 23 censales, por un valor total de 1.600 libras de principal habían sido previamente reconocidos por otro individuo; hecho que, inexplicablemente, ignoraban los administradores de la comunidad ${ }^{(49)}$.

$\mathrm{Al}$ margen de la veracidad de tales acusaciones, los beneficios que obtuvo nuestro hombre merced a su posición de acreedor fueron más considerables. En 1620 dicha comunidad había accedido a la titularidad de una extensa propiedad valorada en 7.830 libras. Pero, al mismo tiempo, sus débitos con $\mathrm{D}$. Jerónimo, sólo en concepto de pensiones atrasadas y otras deudas sueltas contraídas, ascendían ya a 5.904 libras. La oportunidad no podía ser más favorable para intentar hacerse con dicho patrimonio, y así habría de ocurrir. Inmediatamente consiguió que el Azud se lo traspasara en pago de sus atrasos, quedando destinada la diferencia entre ambas cantidades (1.926 libras) al quitamiento de una parte del censal en la cuantía correspondiente ${ }^{(50)}$.

Por otro lado, y a pesar de las pragmáticas que fijaban los tipos de interés del censal en el $5 \%$ del principal, D. Jerónimo siempre se negaría a aceptar la reducción, intentando percibir durante el resto de sus días las pensiones de Alfeytamí al 7,5\%. En 1640, poco después de su muerte, su heredero D. Gaspar accedería a reconocer la rebaja decretada años atrás, pero, al parecer, sólo a cambio de obtener de los regantes exención total de tachas y derramas sobre una buena parte de las tierras que por entonces poseía bajo riego del Azud(51).

\subsection{Relación financiera con la ciudad de Orihuela}

En las relaciones financieras mantenidas con la ciudad de Orihuela, las ventajas obtenidas aún serían más evidentes, en correspondencia con el mayor nivel de endeudamiento alcanzado por ésta. Si en 1611 los censales cargados por el municipio a su favor ascendían a 7.800 libras, en 1623 la deuda consolidada, incluyendo préstamos a interés con los correspondientes réditos y pensiones atrasadas, alcanzaban ya las $14.000^{(52)}$. En 1634 se situaban en torno a las $24.000^{(53)}$ y en 
1639 podían calcularse entre 26 y $29.000^{(54)}$. Este ascenso vertiginoso de la dependencia financiera de la ciudad con respecto a D. Jerónimo no se debió a una mera acumulación de atrasos. Además de las continuas entregas en efectivo -censales, préstamos a cambio, etc.- las relaciones comerciales mantenidas entre ambos también debió contribuir a incremenar la deuda, por impago del importe de algunas transacciones realizadas. Habría que añadir, además que las continuas aportaciones de capital no dejaron de proporcionarle cierta rentabilidad en forma de réditos anuales y, lo que es aún más significativo, importantes concesiones en concepto de gratificaciones especiales.

Las perentorias y crecientes necesidades de la hacienda municipal determinarían una y otra vez el recurso a uno de los escasos financieros que, en cualquier momento, contaba con la solvencia y voluntad precisa para aprontar dinero en efectivo. Y ello habría de ser sobradamente premiado por la ciudad o, más propiamente, por la oligarquía que monopolizaba la administración local.

En un principio, sin embargo, las relaciones no fueron excesivamente cordiales. Así, por ejemplo, en 1616 y a instancias de D. Jerónimo, se obtuvo una provisión de la Real Audiencia de Valencia para que el municipio le reintegrase parte de las 2.640 libras que había entregado en moneda de vellón adulterado. A tal efecto, los jurados consignaron la cantidad correspondiente sobre el arrendamiento de la sisa de la molienda, lo que no satisfizo a Rocamora, quien reclamó el dinero en el acto y consiguió el inicio de las ejecuciones pertinentes ${ }^{(55)}$. Meses más tarde, una provisión real ordenaba el cese y restitución, en su caso, de los posibles embargos realizados ${ }^{(56)}$. El incidente, sin excesiva importancia y probablemente pronto olvidado por ambas partes, habría servido, en cambio, para poner sobre aviso a los dirigentes municipales de cara a futuras relaciones con D. Jerónimo.

Unos años más tarde, a principios de 1619 , la ciudad se veía abocada a una situación de completa bancarrota, mostrándose incapaz de hacer frente al pago de las pensiones que determinados acreedores de Valencia intentaban cobrar por vía ejecutiva(57). Además, urgía realizar acopios de trigo para el pósito, sin que hubiese fondo suficiente para ello(58). Para remediar la situación se propusieron varias medidas de urgencia, entre ellas la venta de un censal de 2.000 libras de principal ${ }^{(59)}$.

Inmediatamente, D. Jerónimo realizaría el desembolso requerido, adquiriendo el censal, por lo que obtendría del consell exención de sisas por 10 años para los nuevos pobladores del señorío alfonsino que, por esas fechas, estaba fundando en su heredad de Benferri( ${ }^{(60)}$. A la semana siguiente prestaba otras 1.200 libras a cambio ${ }^{(61)}$ y cinco meses más tarde, como la situación financiera del municipio distara bastante de mejorar sus perspectivas, entregaba otras $10.000 \mathrm{li}$ bras, en esta ocasión mediante la constitución de censal(62).

El apoyo de la oligarquía oriolana a este tipo de iniciativas señoriales surgidas en su territorio, aunque contaba con algunos precedentes ${ }^{(63)}$, no puede ser entendido al margen de su relación financiera con Rocamora. Especialmente, en un momento en que las voces clamaban por la despoblación que comenzaba a azotar la ciudad y la consiguiente minoración de la recaudación obtenida a través de las sisas. Se trataba, evidentemente, de una importante contrapartida obtenida por 
el poderoso financiero que aún estaba dispuesto a arriesgar su dinero socorriendo las vacías arcas municipales.

La liquidez de nuestro hombre alcanzaría incluso para encargarse personalmente de efectuar el pago de las cargas que anualmente había de satisacer la ciudad. Es, por ejemplo, lo que ocurriria durante el ejercicio económico de 1622, en que le fueron consignadas todas las rentas ordinarias de la ciudad a tal efecto, con la esperanza de que agilizando las transferencias entre las diveras partidas del presupuesto municipal, aún pudiera sobrar un remanente con el cual ir redimiendo censales ${ }^{(64)}$. Sin embargo, ni siquiera así fue posible sanear la hacienda local, cuyos recursos tampoco bastaron para saldar las cuentas con D. Jerónimo, lógicamente uno de los objetivos de la operación. Prueba de ello es que, en 1623, la ciudad reconocía adeudarle más de 14.000 ducados.

Por aquellos momentos, las relaciones entre ambos se enrarecieron un tanto y D. Jerónimo debió comenzar a impacientarse ante las escasas perspecitvas de recobrar al menos una parte de su dinero, lo que motivaria que emprendiese acciones judiciales para ello ${ }^{(65)}$. Pero no era ésta la vía más adecuada para resolver sus pretensiones de liquidez, pues tal y como apreciaba un abogado «la Ciudad ha menester al Sr. Don Gerónimo y el Sr. Don Gerónimo a la Ciudad y siendo partes tan importantes para todo no es bien que anden en pleytos sino que estén muy corrientes y amigas») ${ }^{(6)}$.

Y, efectivamente, a principios del año siguiente, ambas partes llegaban a un acuerdo con intervención de la Real Audiencia, que decretó la forma de pago a seguir, consignando a tal efecto una cantidad anual sobre el arrendamiento del derecho de la molienda y las hierbas de Orihuela hasta su liquidación total(67). Por esas mismas fechas - marzo de 1624-D. Jerónimo, cuyos intereses agrarios cada vez resultaban más patentes, volvía a obtener de los ediles municipales una nueva concesión. Se trataba de una importante extensión de saladares y almarjales contiguos al patrimonio recientemente adquirido a la comunidad de regantes de Alfeytamí ${ }^{(68)}$. Más adelante, al tratar sobre su actividad señorial, volveré sobre el tema; por el momento baste indicar la conexión entre ambos hechos que, aisladamente, resultaría una vez más difícilmente comprensibles.

Ls excelentes contrapartidas que Rocamora había conseguido arrancar a una oligarquía no excesivamente preocupada por salvaguardar los intereses comunitarios explican perfectamente su renuncia a proseguir la vía ejecutiva para obtener la liquidación de sus préstamos. Plenamente consciente del valioso elemento de presión negociadora que suponía mantener esta relación de dependencia financiera y dado que, por otra parte, la ciudad se hallaba incapacitada para cumplir el compromiso acordado ${ }^{(69)}$, en 1625 accede a firmar una nueva transacción con el fin de facilitar el pago reduciendo las consignaciones anuales. Los puntos esenciales del nuevo «acte de consert» eran los siguientes ${ }^{(70)}$ :

- Renuncia recíproca a cualquier pleito instado ante el tribunal del Visitador $^{(71)}$, excepto los concernientes a liquidación de deudas.

-D. Jerónimo tomará a su cargo el avituallamiento de la carne durante dos años, uno forzoso y otro voluntario, a un precio previamente concertado.

- La ciudad consignará anualmente 1.000 libras sobre el derecho de la mo- 
lienda «e aquelles hajen de servir per a que dit Don Gerony se vaja pagant de lo que la Ciutat li deu així de propietats de censals com de deutes solts fins tant sia effectivament pagat de tot lo que se li deun.

- Con respecto a los intereses y pensiones de censales, se obtendrá decreto de la Real Audiencia, consignándose asimismo por la ciudad para su liquidación total.

-D. Jerónimo ha de renunciar al cobro de las 3.100 libras que ha de pagarle este año la ciudad, en virtud del decreto anterior de la Real Audiencia, en esta forma: 2.000 libras las percibirá efectivamente, pero en concepto de quitament de un debitori que se cargó el pósito, y las 1.100 restantes «hajen de ésser per a la Ciutat per a subvenirse».

De este modo Rocamora, aún no desistiendo de la posibilidad de recobrar sus capitales a medio plazo, consentía en demorar el momento en que la deuda fuera totalmente amortizada, asegurándose mientras tanto una renta anual. Por parte de la ciudad, el desembolso de las 1.000 libras que en adelante habría de consignarle resultaba una operación más factible que, efectivamente, pudo llevar a cabo hasta 1630 , en que la consignación se incrementó a 1.200 libras $^{(72)}$. El motivo de este incremento parece haber sido un nuevo préstamo realizado por $\mathrm{D}$. Jerónimo en 1629. No deja de ser curioso que en esta ocasión fuesen los propios jurados quienes tomaran formalmente la iniciativa de pagar un interés por la cantidad prestada, aduciendo los típicos argumentos de la época, para justificarlo(73).

Aún tratándose de la consabida artimaña legalista, no es menos cierto que las relaciones entre ambos atravesaban gran cordialidad. Ese mismo día, los jurados aceptaban la oferta realizada por $\mathrm{D}$. Jerónimo para adjudicarse el avituallamiento de las carnicerías de Orihuela con una condición adicional: el pósito de la ciudad habría de quedar obligado a comprarle 300 cahices de trigo al precio de 5 reales la barchilla, siendo su precio corriente más barato ${ }^{(74)}$. Más aún, ese mismo año obtenía de los jurados la cesión de ciertas ventanas de la casa del pósito, ubicada en la plaza donde se celebraban las corridas de toros, para poder presenciarlas con mayor comodidad, al tiempo que la erección de su escudo de armas, labrado en piedra, en tan público lugar(75).

Pocos años más tarde, en 1632, la petición de un servicio extraordinario a la ciudad por parte de la monarquía brindaría de nuevo la oportundad para que nuestros dos conocidos actores entrasen por enésima vez en escena. Aunque el pésimo estado de las arcas municipales desaconsejaban cualquier esfuerzo financiero, la oligarquía local no podía permitirse una respuesta negativa a la solicitud real. El problema, como siempre, era el modo de obtener el dinero. La solución, no menos novedosa, resultará perfectamente imaginable. Tras varios tanteos y negociaciones que precisaron la intervención directa del Virrey, finalmente se llegaría a un acuerdo: D. Jerónimo facilitaría las 2.000 libras renunciando por el momento a cualquier pretensión de liquidez inmediata; dicha cantidad sería acumulada a los créditos anteriores recibiendo, eso sí, los correspondientes intereses ${ }^{(76)}$.

Para Rocamora, e indudablemente también para la oligarquía local, se trataba de un gesto de generosidad digno de ser recompensado. De no haber mediado su capacidad financiera y su buena predisposición hacia las necesidades de la 
corona, difícilmente hubiera podido cumplir la ciudad con el servicio ofrecido. Y así lo haría incluir en su relación de méritos elevada al monarca pocos años más tarde solicitando el título de marqués (77).

Pero lo que ahora interesa mencionar es la contrapartida inmediata que obtenía por este nuevo empréstito. Porque, efectivamente, al poco tiempo cursaba a los jurados una solicitud para que le establecieran en enfiteusis, por una módica pensión anual, los almarjales cedidos años atrás. Se trataba, pues, de legalizar una situación mediante la adquisición de unos derechos - los derivados de la posesión del dominio útil- sobre unos terrenos cuya titularidad no habría quedado suficientemente clarificada. Huelga decir que la petición sería inmediatamente atendida $\mathrm{a}^{(78)}$.

Desconozco si en lo sucesivo D. Jerónimo volvió a socorrer con su crédito a la ciudad. Hasta la fecha de su muerte - y aún después - los jurados se limitaron a consignar anualmente a su favor las 1.200 libras a que se habían obligado; lo que no implica, necesariamente, que todos los años se hubiesen hecho efectivas. Semanas antes de fallecer, impacientado por las escasas perspectivas de recobrar y aún de clarificar el volumen real de sus créditos con Orihuela, D. Jerónimo no sólo denegaba un nuevo préstamo de 2.000 libras $^{(79)}$, sino que, además, amenazaba seriamente con la ejecución si en el plazo de tres meses no se obtenía declaración de la Real Audiencia sobre el asunto ${ }^{(80)}$. Era este su último intento por obtener un compromiso formal de pronta liquidación, que ya nunca alcanzaría a ver realizado, correspondiendo a su heredero la culminación de esta labor.

La trayectcria indicada acerca de las actividades financieras de nuestro hombre con respecto a las dos comunidades tratadas no contradice en absoluto las tendencias que, a nivel general, parecían presidir su actuación en este ámbito. Al contrario, contribuye a reforzar la imagen del prestamista que domina los mecanismos adecuados para conseguir la máxima rentabilidad de su favorable posición. La constitución de censales, por ejemplo, dejaría de interesarle muy pronto en la medida en que el beneficio quedara limitado simplemente al cobro de una pensión constantemente devaluada. A diferencia de un amplio sector de la sociedad del momento, no era la seguridad de una renta anual lo que buscaba. Sólo un carácter emprendedor, aderezado de una fina intuición para los negocios y respaldado por un poder político y económico en aumento podía conseguir saldar favorablemente la difícil coyuntura que acabaría arruinando a buena parte de sus contemporáneos. Contradiciendo la tónica general que caracterizaría su época, ni siquiera como acreedor había perdido la partida; y ello pese a que nunca pudo ver colmada una de sus más hondas pero continuamente aplazadas aspiraciones: la de haber logrado la total liquidación de sus préstamos. Paradójicamente, la baza jugada por $D$. Jerónimo se basaba ante todo en la debilidad financiera ajena. Pero también en la ausencia de un grupo de poder representativo de los verdaderos intereses municipales. Las oligarquías locales no harían nada, antes al contrario, por detener el imparable ascenso de D. Jerónimo.

\section{Propiedad y explotación de la tierra: transformaciones señoriales}

Por destacada que pueda haber resultado su actividad financiera, nuestro 
hombre brillaría ante todo por los logros obtenidos en relación a la propiedad y explotación de la tierra. En esta faceta, estrechamente vinculada a la anterior y en general a todas las desarrolladas, su preocupación fundamental estaría constantemene orientada hacia las formas de propiedad señorial, llegando a constituir su acumulación, más que una simple aspiración, una auténtica obsesión vital. Buena prueba de ello es, de nuevo, la intención expresada en el ya mencionado testamento de 1626 - cuando habia conseguido alzarse con varias titularidades señoriales- al disponer la prohibición de vender o enajenar los censales cargados sobre ciudades «si no serà per a comprar algun lloch o altra pocessió contigua als dits llochs $)^{(81)}$.

Sin embargo, más que a la adquisición de señoríos ya constituidos, su labor va a dirigirse a la propia creación -no siempre a tenor del privilegio alfonsino-, sobre la base de terrenos previamente apropiados a través de diversos mecanismos. Pero siempre, y hay que insistir en ello, desde la más absoluta legalidad para evitar futuras reclamaciones sobre derechos de propiedad. Adelantando acontecimientos, habrá que decir que la propiedad plena de la tierra anticipó en todos los casos a su posterior transformación en propiedad señorial.

En principio, podría sorprender el empeño por emprender nuevas creaciones señoriales en una época en que muchos de los anteriormente constituidos atravesaban no pocas dificultades para su repoblación, derivadas del vacío provocado por la expulsión de los moriscos. En el propio entorno comarcal, los señores de Albatera, Cox, La Granja, intentaban por todos los medios atraerse colonos a sus despoblados, provocando las protestas de la ciudad de Orihuela que, de este modo, veía disminuir sus efectivos ${ }^{(82)}$. Pero esto no desanimó a $D$. Jerónimo, quien unos años más tarde conseguía convertirse en señor de vasallos por triplicado y a punto estuvo de obtener un cuarto señorío.

Es precisamente este intento fallido el que marca los primeros pasos avanzados en el sentido indicado. Se trataba de la adquisición del señorío de Redován, secuestrado largo tiempo por la Real Audiencia bajo el peso de las deudas contraídas por sus señores, y cuya adjudicación fue repetidamente sacada a pública subasta. En 1614 D. Jerónimo no sólo manifestaría su deseo de compra, realizando la correspondiente oferta, sino que incluso llegaría a un acuerdo con los vasallos del lugar redactando los capítulos de población que habrían de regir en el fúturo las relaciones señoriales en caso de ser rematado a su favor. Sin embargo, sería el Colegio de Predicadores de Orihuela quien acabaría adjudicándose definitivamente el señorío, por un precio de 12.000 libras $^{(83)}$.

Es difícil adivinar los motivos de esta retirada final de Rocamora. ¿Acaso aún no estaba en condiciones de competir con la poderosa institución religiosa oriolana? ${ }^{(84)} \mathrm{O}$, ¿debió comprender a última hora que era preferible partir de bases diferentes para su estrategia señorial; más concretamente, de aquellas otras que excluyeran posibles derechos por parte de los pobladores ya previamente asentados? ${ }^{(85)}$ Ciertamente, su trayectoria posterior parece confirmar esta últimá hipótesis.

\subsection{El señorio de Benferri}

Hacia 1622, un erudito cronista local, buen conocedor de su entorno - se 
trataba de Mosén Pedro Bellot- señalaba con respecto a Benferri que «en la conquista no era más que una torre» y que en 1494

«Don Jaime Rocamora lo comenzó a poblar haciendo casas, pero mucho más lo ha mejorado su hijo don Gerónimo, haciéndole lugar formado con jurisdicción e Iglesia. Y en el año 1622 le dió posesión de jurisdicción don Juan Ferrer de Calatayud, Gobernador»(86).

Dejando a un lado el craso error de apreciación en cuanto se refiere al parentesco mencionado - o quizás a la fecha indicada al principio - las notas de Bellot sugieren la existencia de un intento repoblador años atrás, que sólo culminaría merced a la acción emprendida por D. Jerónimo. El significado exacto de la transformación operada en Benferri requiere, sin embargo, de algunas precisiones. En particular, interesa discutir al menos, puesto que resultará difícil llegar a conclusiones definitivas, cual era la situación real de Benferri antes de su conversión en señorío y qué supuso la citada colonización.

Aunque no es este el momento de analizar su evolución a partir del momento de la conquista, quizás convenga señalar, en principio, que con dicho topónimo se aludía tanto a una partida rural, ubicada en el campo de Orihuela, como a una posesión particular incluida en aquella. Tal y como refería un testimonio de 1582 «en la dita partida de Benferri y enves la part de Favanella y

Charco del Alcayt estan heretats los vehins y habitadors de la Ciutat de Oriola, cavallers, ciutadans y llauradors y en dita partida ab antiquo tenen ses laurons ${ }^{(87)}$.

Para estas fechas, sin embargo, los Rocamora habian conseguido acumular buena parte de las heredades que integraban dicha partida. Además de otras incorporaciones ${ }^{(88)}$, la adquisición principal se había producido en 1464 , cuando D. Juan Rocamora compraba la «heretat y torre» llamada precisamente de Benferri, siendo ésta la que habría de constituir el núcleo del futuro señorio( ${ }^{(89)}$. Se trataba, no obstante, de una propiedad un tanto peculiar puesto que, según cierta sentencia de 1496 pronunciada a instancias de Mosén Pere Rocamora, «Señor del heretament de Benferri»

«fonch provat ab moltes testimonis lo lloch e heretament de Benferri ésser cavalleria antigua e los senyors de dit heretament estar en posesió y haver acostumat de arrendar lo dret de amprivar e herbejar de dit heretament... e no obtant dit arrendament los vehins y habitadors de la Ciutat de Oriola poder amprivar ab sos bestiars en los límits del dit heretament»(90).

Términos como senyor, lloch y cavalleria antigua, así como el derecho a la libre disposición de las hierbas - ratificado por sentencias posteriores ${ }^{(91)}$ - sugieren que se trataba de algo más que de una mera propiedad. En cuanto a la hipotética condición de lugar, hay que entenderlo fundamentalmene, en el mejor de los casos, como una agrupación de viviendas y no como categoría municipal con propia entidad jurídico-administrativa ${ }^{(22)}$. Las otras expresiones mencionadas hacen suponer, en cambio, un origen como antigua infeudación que habría posibilitado a sus titulares detentar ciertos derechos jurisdiccionales y, en consecuencia, tomar el apelativo de señores. El hecho de que no se hubiera alcanzado -hasta que lo hiciera D. Jerónimo- el nivel definido por el fuero alfonsino, demuestra 
que el pretendido asentamiento humano hubo de ser bastante precario(93). En parte, como veremos más adelante, por la inexistencia de establecimientos.

El caso de Benferri a principios de la edad moderna podría incluirse, por tanto, entre un cierto tipo de señoríos de escaso nivel jurisdiccional, bastante extendidos en el territorio valenciano, pero aún mal conocidos ${ }^{(94)}$.

El que, en años posteriores, la titulación mencionada tendiera a desaparecer y los propietarios de la heredad de Benferri dejaran de referirse a cualquier alusión señorial podría indicar que, con el tiempo, habría perdido cualquier contenido efectivo, pero no necesariamente ${ }^{(95)}$. Sobre todo, cuando es posible detectar la presencia de efectivos humanos.

La descripción que en 1588 hacía su vinculador -el padre de D. Jerónimocalificaba a Benferri como una heretat ubicada en los términos generales de la ciudad de Orihuela

«plantada de oliverals y morerals y molta diversitat de altres arbres així terra blanca com plantada secans com regadius les quals terres se reguen dels vertens y de la rambla de Benferri y de les aigües que naixen en les fonts de terme de Favanella senyaladament yo tinc comprat sert tros de terra en les fonts nomenades de les Anguiles y en la terra que yo tinc comprada naix dos fontes segons consta ab acte, y juntament ab dita terra y font la partició de un altre heretat de Favanella en la qual heretat ay una torre antigua, y junt a dita torre ay un Aljup la mitat és de dita heretat y la altra és de Don Joan Rocamora Senyor de la Granja, y la mitat del Corticho que per áy va la partición)(96).

Quedaba expresado de este modo cómo el proceso de incorporación de tierras anexas no se había detenido pero, al mismo tiempo $-\mathrm{y}$ según consta por otros documentos ${ }^{(9)}$ - la original heredad de Benferri ya habia sido dividida, recayendo una parte en el Señor de La Granja, en cuya casa habría de permanecer definitivamente. La participación habría afectado incluso a edificios como el aljup y el cortijo, que señalaban precisamente los límites entre ambas heredades. Ninguna alusión, por lo demás, a cualquier indicio de señoría o atribución jurisdiccional expresa.

Sin embargo, la referencia a núcleos de habitación para posibles cultivadores hacen sospechar otra realidad distinta. Así, al concretar los límites de la heredad, se mencionaban «algunes casses y edifisis de balses y algups de dita

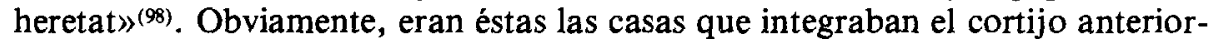
mente citado, configurando un tipo de habitat rural nada infrecuente en otras heredades del entorno cuyos titulares pretendían gozar por entonces del ejercicio de la jurisdicción civil(99).

En principio, la propia existencia de estas formas de poblamiento plantea el problema de las relaciones que vinculaban a sus moradores con la tierra que cultivaban, pero también con su titular.

Un documento posterior, de 1610, aunque no acaba de despejar estas incógnitas, permite centrar aún más la discusión. Me refiero ahora a un contrato de arrendamiento de la heredad de Benferri suscrito ese año por $D$. Jerónimo a favor de un particular: Miguel Lozano ${ }^{(100)}$. Más que las sorprendentemente escuetas condiciones con que se otorgó la escritura ${ }^{(101)}$, interesa destacar una doble men- 
ción: en primer lugar, la cesión del usufructo temporal de «una heretat de cinch mil tafulles poch més o menys, pechos de terra ab una casa y una almasara»; en segundo término, la referencia, en los límites de la heredad, a «les cases del terragers».

Tal y como aparecen caracterizados en la documentación coetánea, los terragers eran cultivadores que entregaban una parte en la cosecha en especie, independientemente de su vinculación jurídica con respecto a la tierra. Será necesario, pues, precisar si se trataba de enfiteutas o de aparceros o, incluso, si guardaban cierta semejanza con los exáricos detectados por Primitivo Pla en otras zonas regnícolas de población morisca ${ }^{(102)}$.

La expresión pechos de terra tampoco aclara mucho en este sentido, pero al constatar que en el arrendamiento citado no se menciona en ningún momento elemento alguno referido a la enfiteusis, cuando lo habitual en tales contratos era que el arrendador hiciera explícita reserva de la señoría directa -en caso de que la hubiera - o incluyera algunas precisiones sobre la división de dominios, ha de concluirse que dichos terrajeros no disfrutaban de derechos permanentes sobre la tierra que cultivaban. En otras palabras, no habrían alcanzado la categoría de enfiteutas.

A título comparativo, y aunque la situación no necesariamente haya de ser extrapolable, quizá resulte esclarecedor observar el régimen de explotación adoptado en la vecina heredad perteneciente al señor de La Granja que, como ya se indicó, se había segregado por partición de la primitiva heredad de Benferri. En 1613, su titular, D. Francisco Rocamora y Maza, la cedía también en arrendamiento al mismo individuo - Miguel Lozano-que desde tres años atrás se había convertido en el arrendatario de la perteneciente a D. Jerónimo. Pues bien, en este contrato suscrito por el señor de la Granja se incluía una cláusula tan significativa como la siguiente:

"Que los vehins e habitadors del dit lloch de la Granja vasalls... tots temps que els parexerà puxen llaurar y sembrar en les terres de dita heretat ahon vós dit Losano los señalareu y collir los fruïts pagantvos lo terrage de les tals terres que així se sembraran a vosaltres dits cónyuges sens que vosaltres dits cónyuges los hi puxa' contradir ${ }^{(103)}$.

¿Eran éstas las condiciones en que los terrageres de D. Jerónimo cultivaban las tierras de Benferri? Podría aducirse que, efectivamente, no debieron ser muy diferentes y que, si en el arrendamiento efectuado por D. Jerónimo no figuraban cláusulas de este tipo quizá se debiera a que no se previeron posibles conflictos del arrendatario con los terrajeros, o bien a que éstos disponían de unas parcelas perfectamente delimitadas para su explotación.

De cualquier modo, la condición de estos cultivadores bien podría ser caracterizada como aparceros sin derechos legales sobre la tierra, cuyo dominio absoluto pertenecía al propietario, quien, además, decidía sobre la estabilidad de la explotación familiar. Por otro lado, resulta difícil saber si esta situación derivaba de una relación de vasallaje personal ${ }^{(104)}$.

En estas circunstancias la rentabilidad de tan extensa heredad venía determinada no tanto por la capacidad productiva de los terrajeros, como por la del 
arrendatario o de aquel que asumiera los gastos de su explotación directamente. Pero, en última instancia, la viabilidad de esta forma de explotación dependía sobre todo, de las disponibiliades de mano de obra. Cuando la escasez de brazos comenzara a representar un serio problema en la comarca, habría que acudir a otros modelos que evitasen una ruinosa depreciación de la tierra por dejación de su cultivo. A todo ello habría que añadir las presiones de un campesinado que trataría de reforzar su posición exigiendo mayores garantías de estabilidad mediante la adquisición de ciertos derechos sobre la tierra.

En este contexto la colonización señorial en virtud del fuero alfonsino podía cumplir perfectamente dichos objetivos y a ello acudió D. Jerónimo en cuanto hubo expirado el anterior contrato de arrendamiento de 1610 , suscrito por ocho años. A principios de 1619 declaraba haber fundado el lloch de Benferri, con más de 29 vecinos «y té determinat il.lustrar aquell ab altres nous edificis y cases en les quals pugan habitar més vehins»(105).

Para facilitar la operación colonizadora recurrió - como ya sabemos-a los jurados de Orihuela, solicitando exención de sisas para sus nuevos vasallos por un tiempo de 10 años, en conformidad con un acuerdo del consell adoptado en 1543 que así lo preveía ${ }^{(106)}$. Aunque la concesión en modo alguno podía ser obligatoria, la respuesta no se hizo esperar:

«Per quant la dita Ciutat esta en costum de concedir semblants gràcies a les perçones quic funden nous pobles per lo llustre que reb la cosa pública de la dita Ciutat ab semblants noves poblations aumentant la jurisdictió dels ordinaris de dita Ciutat y també per que en son temps la dita Ciutat serà aumentada en ses rentes ab los delmes y altres pertinències. $E$ attes que per la nova població de Benejússer fonch concedida semblant gràcia a don Jaume Rosell señor de Benejússer. Per tant com la dita Ciutat deja amar ygualment a sos vehins y més als que tant se précien favorir-la ab la present fan gràcia al dit Don Hieroni Rocamora y habitadors del dit poble de que per temps y terme de deu anys contadors del dia de huy en avant no paguen sisa alguna als arrendadors de dita e present Ciutat... ab la condició de que sempre y quant lo consell determinarà altra cosa los pobladors del dit lloch de Benferri pagaran les dites cisses com les demés vehins ${ }^{(107)}$.

De este modo, imitando el proceder del colonizador de Benejúzar y contando con el parabién de la ciudad, D. Jerónimo se convertía en nuevo señor alfonsino, por mucho que los jurados intentaran disimular lo que ello representaba. No deja de ser sorprendente que Orihuela alentase semejante iniciativas puesto que, en definitiva, estos nuevos señoríos surgían dentro del tradicional ámbito realengo de la ciudad e implicaban un menoscabo de su jurisdicción. A excepción del debido favor a nuestro hombre, por motivos ya conocidos, el resto de los argumentos esgrimidos parecen difícilmente justificables. Más aún, ni siquiera a título particular, como propietarios que eran, la oligarquía de la ciudad podía estar objetivamente interesada en fomentar la competencia que ello podía ocasionar por hacerse con una mano de obra no precisamente excedentaria. Y así lo revelarían sin ambages con motivo de la repoblación posterior a la expulsión de los moriscos ${ }^{(108)}$. 
Pero volviendo a la nueva organización del señorío de Benferri, es obvio que la adquisición de la jurisdicción alfonsina por el señor no habría de encontrar graves dificultades, toda vez que se hubo superado con creces el mínimo exigido de 15 pobladores ${ }^{(109)}$. Como tampoco habría de constituir especial problema su transformación en entidad municipal, mediante la creación de magistrados ${ }^{(110)}$.

En cuanto al régimen de tenencia adoptado, es lógico suponer que se hubiera recurrido al establecimiento enfitéutico como fórmula más adecuada para atraer pobladores, al menos en una proporción suficiente para asegurar un primer asentamiento. Aunque desconozco cualquier referencia a carta puebla alguna y tampoco me ha sido posible localizar ningún establecimiento individual, el único dato coetáneo de que dispongo sobre el particular apunta en esta dirección. Se trata de una escritura de venta de una pequeña parcela de moreral, otorgada por un vecino de Benferri en 1631

«per franques e quites exceptat lo dret que's paga al senyor de dit lloch que's de set moreres una»(111).

Obviamente, la facultad para vender presupone un derecho de propiedad, correspondiente en este caso al dominio útil, mientras que la partición de frutos al séptimo representaría el canon anual debido al señor por el dominio directo.

Aparte de los nuevos derechos procedentes de las posibles regalias y del ejercicio de la jurisdicción señorial, con todo lo que suponía el control sobre el territorio y sus vasallos, la colonización posibilitaba someter la vasta extensión de Benferri a un aprovechamiento más intenso mediante la aplicación de unidades crecientes de trabajo. Aunque el señor tuviese que ceder a cambio parte del dominio útil, la repoblación aportaba la mano de obra necesaria, ya no sólo para el más adecuado cultivo de las tierras establecidas, sino también para aquellas que se había reservado en dominio consolidado ${ }^{(112)}$.

Realizaciones de este tipo, frecuentes en momentos de escasa presión demográfica y desvalorización de la tierra -entre otras circunstancias- habría que asimilarlas más que a un regresivo proceso de refeudalización a una racional planificación de la empresa agraria ${ }^{(113)}$. En 1622, el propio D. Jerónimo insistía en las inversiones realizadas en mejoras de la explotación:

«y que en los dits béns vinculats e fet yo dit testador moltes millories exhampliant la cassa on de present abite encorporant en aquella altres casses et etiem e fet lloch format en !a heretat de Benferri fent casses, alyups, almàsera per a fer oli e adquerint aygua viva per a regar les terres y tafulles de dit Benferri y he comprat moltes terres y heretats de particulars sircunsvehins encorporant-les en dit lloch»(114).

Aunque parte de ellas habría que atribuirlas en realidad a la labor de su padre, resulta elocuente la vinculación que se pretende establecer entre el acondicionamiento de la explotación mediante la construcción y dotación de una infraestructura que permitiese una mayor rentabilidad y el consiguiente aumento del valor del patrimonio. Las sucesivas incorporaciones de parcelas limítrofes, siguiendo las prácticas de sus predecesores, alcanzaban ahora nueva dimensión puesto que significaban la ampliación del territorio señorial, con las implicaciones que de ello se derivaban a nivel jurisdiccional. Este procedimiento habría de ser repe- 
tidamente practicado en otros señoríos de la comarca y acabaría provocando posteriormente las protestas de la ciudad, cuando se llegó a tomar conciencia del continuo retroceso que venía experimentando el término realengo ${ }^{(115)}$.

\subsection{La Baronía de La Puebla}

$\mathrm{Al}$ año siguiente de la fundación de Benferri, $\mathrm{D}$. Jerónimo conseguía acceder a la plena titularidad de unas tierras ubicadas en el señorio baronal de Daya Nueva; circunstancia que, en principio puede parecer un tanto sorprendente, toda vez que dicho señorío se hallaba perfectamente vinculado en su integridad. Pero veamos detenidamente el proceso.

La baronía de Daya Nueva era un antiguo señorío enclavado en la huerta del Bajo Segura cuyos titulares habían obtenido, en 1334, la jurisdicción de mero y mixto imperio ${ }^{(116)}$. A través de sucesivas transmisiones, el patrimonio señorial ha-

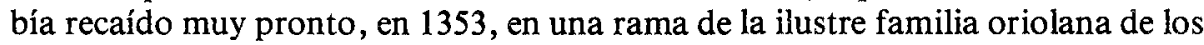
Masquefa, cuyos miembros consiguieron conservarlo en su poder durante los tres siglos siguientes, no sin graves dificultades para ello ${ }^{(117)}$.

A finales del Quinientos, los regantes del Azud de Alfeytamí, entre los cuales se encontraba como mayor propietario el señor de la Daya, determinaban la remodelación de la presa construida en el Segura con la finalidad -entre otrasde beneficiar más ampliamente la huerta, incrementando la dotación de aguaa(118) A tal efecto, la comunidad de regantes, para sufragar el costo de la obra, decidía el cargamiento de los censales necesarios y la imposición de derramas para su posterior liquidación ${ }^{(119)}$. No cabe ahora detenerse en la descripción del mecanismo de financiación seguido, las dificultades que presentó o los intereses y conflictos que motivó, pero sí conviene destacar algunos aspectos que interesan particularmente a nuestros fines.

En 1609, tras una serie de concordias y tentativas infructuosas, el señor de la Daya, cuyas tierras se regaban del citado Azud, era ya deudor a la comunidad en más de 8.000 libras, lo que motivaría - a instancias de ésta- una sentencia ejecutiva ordenando el secuestro de sus bienes «mobles y semovents» de cuyo producto habrían de liquidarse ias deudas contraídas ${ }^{(120)}$. Como ello no fuera suficiente, unos años más tarde, en 1616, una nueva sentencia iría aún más lejos decretando la subasta y venta de una parte de las tierras de dicha baronía; concretamente "quantes sien necesaries y baste per a pagar tot lo credit del dit Asut»(121). De nada servirían las apelaciones posteriores, basadas en argumentos de todo tipo, de tal modo que a principios de 1619 se abría la subasta, previa relación de expertos acerca de los distintos tipos de tierra y su correspondiente valor ${ }^{(122)}$. Al poco tiempo, y al no presentarse más oferta que la del propio síndico del Azud, en nombre de la comunidad, sería ésta quien finalmente acabaría adjudicándose el lote señalado a un precio de remate del $68 \%$ de su valor estimado(123).

De este modo, D. Salvador Masquefa asistía a la desmembración de 2.010 tahúllas de su patrimonio señorial, cuya valoración, por otra parte, aún no era suficiente para saldar definitivamente las cuentas con los regantes, lo que provocó que las instancias en su contra prosiguieran durante buena parte de la centuria ${ }^{(124)}$. 
Una vez más quedaba en evidencia las nefastas consecuencias de la insolvencia de ciertos sectores de la nobleza valenciana para hacer frente a sus acreedores.

Por su parte, la comunidad de regantes recibía a cambio de la liquidación en efectivo de la deuda a que era acreedora, una extensa y valiosa propiedad que, por el momento, podía contribuir a solucionar gran parte de sus propias dificultades financieras. Porque, no hay que olvidarlo, también ellos se hallaban inmersos en un progresivo estado de endeudamiento por impago de pensiones de los censales contraídos. Fundamentalmente, con D. Jerónimo, como ya se ha indicado anteriormente. Dada esta vinculación financiera y la siempre problemática posibilidad de rentabilizar la explotación recién adquirida por parte del colectivo, no es difícil preveer, por tanto, lo que iba a suceder a continuación.

En efecto, a finales de 1620 el síndico de Alfeytamí traspasaba la titularidad de las 2.010 tahúllas a Rocamora, en pago de una parte de las deudas que había contraído con él ${ }^{(125)}$. El carácter premeditado con que fue realizada la mencionada operación parece evidente a tenor de las siguientes circunstancis. En primer lugar, por haber sido D. Jerónimo quien costeó desde sus inicios el pleito instado por los regantes contra el señor de la Daya, adelantando el dinero necesario ${ }^{(126)}$. Pero además - de haberse podido demostrar la certeza de cierta acusación - por un posible intento de soborno para que Masquefa consintiese en la ejecución y remate de las tierras a favor del Azud a cambio de 500 libras entregadas en efectivo por nuestro hombre ${ }^{(127)}$.

Aprovechando la favorable situación presentada, D. Jerónimo conseguía así añadir a su patrimonio una nueva adquisición al $68 \%$ de su valor estimado y sin tener que hacer efectiva la cantidad correspondiente. La calidad de las tierras en el momento de su toma de posesión, 1620 , era la siguiente ${ }^{(128)}$

\section{CUADRO IV}

Tierras que integraban la futura baronía de La Puebla, 1620.

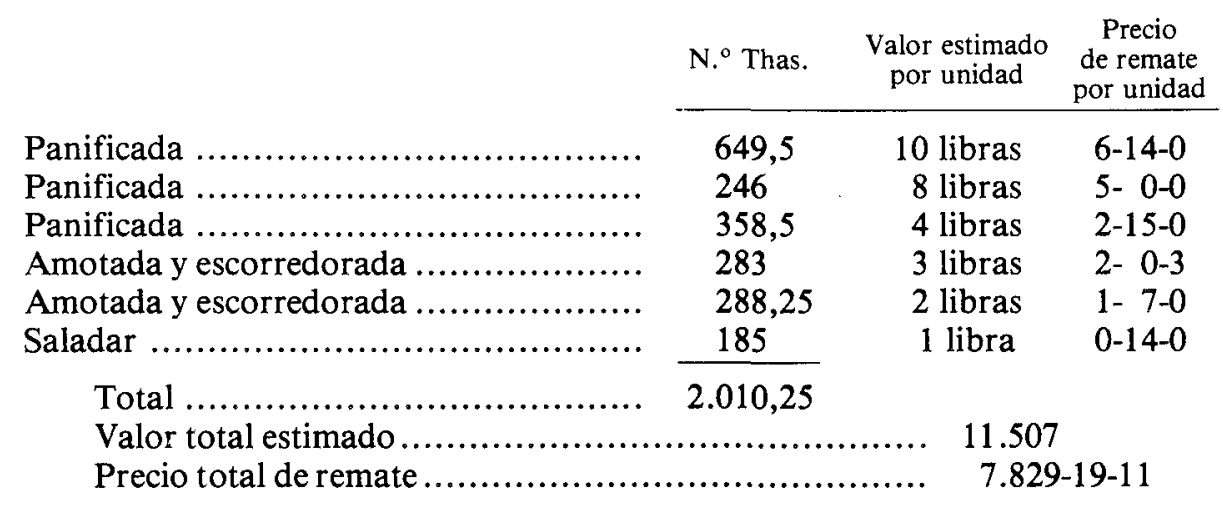

Como podrá observarse, se trataba de tierras no excesivamente valiosas, pero susceptibles de serlo mediante una serie de inversiones adecuadas, pues tal y como exponía el procurador del señor de La Daya a principios de 1621, «la qual 
terra y tafulles contengudes en dita offerta tunc temporis estaven llaurades y fetes escorredors y ben acomodades lo que huy no estan per culpa y necligència de la part contrària»(129).

En un primer momento y posiblemente a consecuencia de la conflictividad desatada en los años subsiguientes a lo que el señor de La Daya no dejaba de considerar como una injusta expropiación, las condiciones no debieron ser excesivamente propicias para su puesta en cultivo(130), por lo que D. Jerónimo decidió destinar al apacentamiento de su extensa cabaña ganadera los terrenos menos productivos ${ }^{(131)}$. Sin embargo, años más tarde, procedía a la apertura de nuevos edificios de riego para beneficiar su nuevo patrimonio ${ }^{(132)}$.

Pero la creación de señoríos se iría convirtiendo poco a poco en una obsesión y pronto llegarían las iniciativas orientadas a este fin. En 1624, en una petición dirigida a los jurados de Orihuela, ya señalaba como siendo «señyor y posehidor de dos mil y més tafulles que solien ser del senyor de la Daja... tendria resolt de fer y edificar un lloch» ${ }^{(133)}$.

Unos años más tarde, en 1629, aún no había conseguido ver enteramente cumplido su objetivo, aunque parece ser que ya debía hallarse en avanzado estado de gestación. El anónimo autor de un informe elaborado por entonces señalaba entre los bienes de $\mathrm{D}$. Jerónimo, «la mejor y mayor parte del término de la Daya, donde a comenzado a fundar un lugar» (134).

La estrategia seguida, podría pensarse en buena lógica, habría consistido en ir asentando pobladores sobre el patrimonio adquirido con el propósito de cumplimentar los 15 vecinos necesarios para alzarse con la jurisdicción alfonsina. Sin embargo, parece bastante improbable que consiguiera atraer el mínimo requerido por el fuero de 1329, si es que alguna vez se lo propuso seriamente. En consecuencia, en 1631 recurría a la corona para obtener el mero y mixto imperio sobre el lugar recién levantado, al que llamó Puebla de Rocamora, así como la facultad para construir un molino en su término. Ofrecía por todo ello 22.000 reales castellanos, cantidad suficiente para que la petición fuera debidamente atendida ${ }^{(135)}$.

$\mathrm{La}$ adquisición de la jurisdicción baronal permitía a su titular afianzar su posición sobre un territorio que ofrecía no pocos problemas de cara a su transformación en señorío meramente alfonsino. Entre otras razones, por la indefinición jurisdiccional en que habría quedado la base territorial que llegaría a constituir el núcleo del nuevo señorío. No hay que olvidar que las 2.010 tahúllas referidas habían formado parte de un término baronal y que su transmisión podía interpretarse que afectaba únicamente a la propiedad de la tierra, sin que por ello hubiera de seguirse menoscabo de los derechos jurisdiccionales detentados por el señor de La Daya. En definitiva, resultaba más que dudoso que la jurisdicción se hubiese enajenado conjuntamente con la propiedad.

Sin embargo, aunque fuera éste el criterio que parecía imponerse, el modo más eficaz de evitar futuras controversias consistía en la obtención de un nivel jurisdiccional sobre el término segregado que garantizase su inmunidad e independencia efectiva. Una vez alcanzado el mero y mixto imperio quedaría definitivamente sancionada su desvinculación con respecto a la baronía de La Daya a todos los niveles posibles. Al propio tiempo, ello relevaba a $\mathrm{D}$. Jerónimo de cumplir las condiciones requeridas por el fuero alfonsino para la creación de señoríos. De forma explícita, el asentamiento de un mínimo de 15 pobladores; de mo- 
do implícito, tener que recurrir al establecimiento de gran parte de la tierra como factor de atracción colonizadora.

Respecto a la primera cuestión, e 3 indudable que hasta bien entrado el siglo XVIII La Puebla jamás llegaría a alcanzar dicho cupo demográfico(136), circunstancia estrechamente vinculada al escaso relieve o total inexistencia del segundo aspecto mencionado. Parece ser, efectivamente, que el establecimiento enfitéutico, en caso de haberse prodigado en un principio, lo habria hecho en proporciones despreciables en comparación con otras formas de tenencia y explotación de la tierra que implicaban su plena propiedad por parte del señor. Al menos, la totalidad de las referencias que conozco sobre el particular -coetáneas y posteriores-, si bien no suficientemente explícitas en la medida que sería deseable, ignoran completamente la existencia de establecimientos. Sirva como muestra el inventario realizado en 1639.

«Ittem lo lloch y Baronia de la Puebla de Don Geroni ab tota jurisdictió civil y criminal, mer y mixt imperi ab (en blanco) casses forn, taverna, panaderia, tenda, carniseria y Yglesia y ab totes les regalies pertanyents al dit lloch qu'està situat en los termens generals de dita e pressent Ciutat entre la Universitat de Almoradí y lo lloch de la Daja ab dos mil y deu thafulles en aquell part moreral y part terra blanca sots rech de la Cequia Nova de Almoradí que afronten de una part (en blanco).

«I ttem (en blanco) bous per a la llauro de les dites thafulles de la Baronia de La Puebla ab los quals les llauran quatre llauradors quinters ab dos parells cascu.

«I ttem (en blanco) aladres (en blanco) relles (en blanco) jous (en blanco) trasgues ab exenguers de la llauro de la dita Baronia de la Puebla»(137).

Cabe aventurar, por tanto, que D. Jerónimo debió mostrarse bastante reticente a desprenderse del dominio útil de la tierra mediante la cesión de establecimientos, lo que no impidió que consiguiera atraer un mínimo de pobladores que cultivasen su propiedad.

Otra hipótesis que habría que mencionar, aunque la considero improbable, consistiría en la posibilidad de que algunos vasallos de la Daya, cultivadores tradicionales de una parte del territorio enajenado, consiguieran hacer valer sus derechos forzando al nuevo señor a aceptar su condición anterior. Poco antes de que D. Jerónimo entrase en posesión del territorio, cuando ya había sido adjudicado a los regantes de Alfeytamí,

«Franses Baro, Agostí Alfagari e Gaspar Masquefa, vehins y habitadors del lloch de La Daja procuren y cultiven algunes dels dites terres y ab aver-los advertits que aquelles son propries del dit Assut per aver-les comprades y presa poseció de elles no és estat posible que dits particulars deixasen dites terres al dit Assut»(138).

Es difícil suponer, no obstante, que entre las 2.010 tahúllas subastadas se hubieran incluido precisamente aquellas cuyo dominio útil pertenecía a los vasallos de La Daya, toda vez que el señor disponía de una proporción mayor en dominio consolidado que, lógicamente, tenían preferencia ejecutiva ${ }^{(139)}$. Los derechos so- 
bre la tierra que pudieran haber ostentado los cultivadores mencionados debían ser, por tanto, bastante precarios y apenas rebasarían los derivados del arrendamiento o la aparcería, lo que no habría de suponer especiales dificultades para su desahucio posterior. Aún así, esto no descarta completamente su reconversión, mediante acuerdo, en vasallos del nuevo señor.

De cualquier modo, a tenor del inventario de 1639 , nos encontramos ante una baronía concebida fundamentalmente como empresa agraria en la que el señor aporta los instrumentos de producción, recauda la quinta parte de la cosecha y - lo que aquí conviene destacar - conserva la plena titularidd de toda o la mayor parte de la propiedad de la tierra. Todo ello, además de los derechos que en concepto de regalías le pertenecían, así como los derivados del ejercicio de la jurisdicción de mero y mixto imperio.

De confirmarse esta situación para el conjunto de término señorial, la creación de la baronía de la Puebla de Rocamora y su propia existencia en cuanto tal representaría un caso atípico en la caracterización del régimen señorial valenciano en la época moderna.

Con todo, las ambiciones de $\mathrm{D}$. Jerónimo con respecto al nuevo señorío iban mucho más lejos de lo señalado. Como las instancias de los acreedores contra D. Salvador prosiguieran aún después de 1620 , llegó a plantearse la necesidad de ir subastando todos los bienes que integraban su patrimonio. En 1622 se procedía a un minucioso justiprecio de todas las tierras, casas y edificios -incluidas las establecidas- que componían la baronía de La Daya; y en 1628 D. Jerónimo realizaba la correspondiente oferta a un $66,6 \%$ de su valor pericial ${ }^{(140)}$. De haberse llevado a efecto el remate definitivo, hubiera significado, sin duda, la mejor operación realizada por nuestro hombre, puesto que la estimación se había realizado como si de cualquier propiedad se tratase, individualizando únicamente el valor de los inmuebles sin tener en cuenta la jurisdicción señorial y los derechos inherentes a ella. Tal y como había expresado otro sospechoso pretendiente, años atrás,

«que la dita Baronia de la Daja no es vaja venent per particulars y a trosos perque de aquesta manera se deminuirà molt lo preu de aquella ademés que és cossa no platicada ni en rahó admisible vendres una Baronia truncadament $\rangle^{(141)}$.

La razón era clara:

«per partes se perdia absolutament lo títol de Baronia y la jurisdicció alta y baixa mer y mixt imperi... puix es cossa molt notoria y practicada que en la estima que es fa de una Baronia se considera lo valor a rahó de vint sous per cada sis diners, y les terres sols se venen per la estima y encara que per un ters meins similiter les casses pendran son valor $\mathrm{y}$ també les regalies, $\mathrm{y}$ en efecte no es traurà de dita Baronia venuda per parts la decima part del que es traurà venuda en junt»(142).

Sin embargo, D. Jerónimo muy pronto se encontraría con otro personaje a su medida, una mano poderosa que contrarrestara su influencia y poderío. En 1629, D. Ramón de Rocafull, Conde de Albatera, obtenía donación de La Daya e iniciaba una firme oposición a las causas de ejecución instadas contra la baronía, 
consiguiendo finalmente paralizar el proceso con motivo de su participación en las cortes de Castilla de 1632, como procurador del reino de Murcia( ${ }^{(143)}$.

La frustración de D. Jerónimo en su intento por hacerse con todo el término territorial de La Daya quizá debió influir en la decisión de convertir al menos la parte ya apropiada en cabeza de un nuevo señorío, solicitando para ello la jurisdiccional baronal.

Antes de todo ello, sin embargo, Rocamora ya había conseguido incorporar de hecho a su nuevo patrimonio la utilización de unos terrenos contiguos. Como ya sabemos, aprovechando su ventajosa posición de acreedor, en 1624 solicitaba a los jurados de Orihuela la concesión de una considerable extensión de almarjales y saladares realengos, anexos a sus posesiones. Petición que habría de merecer la siguiente respuesta:

"Atenent los servisis que dit Don Geroni a fet y fa a dita Ciutat y que el dar-los és en molt gran utilitat y embelliment de aquella fan gràcia y merset de aquellas al dit Don Geroni Rocamora y als seus dels dits almarjals y saladars contigos a dites terres la qual grácia entenen fer y haver fet sens perjuhí de terser algú y axí li fan la dita grácia y mersed cum omnibus juribus que dita Ciutat podia tenir en dits almargals y saladars instituhint-lo ad aquell verdader senyor ${ }^{(144)}$.

Aunque los términos en que había realizado la cesión de los saladares parecían indicar una transmisión del dominio pleno, en la práctica quizás debieron surgir algunos problemas para monopolizar su utilización, toda vez que -como explícitamente se había declarado-- no había de perjudicar derechos de terceros. Entiéndase por esto, derechos comunales sobre su libre aprovechamiento. Por otra parte, enajenaciones de este tipo implicaban, de hecho, que los jurados se reservaban el derecho de recuperar su dominio cuando el beneficiario, transcurrido cierto tiempo, no había conseguido su puesta en cultivo. En 1597, por ejemplo, los jurados determinaron la anulación, con el consiguiente reintegro, de todas las cesiones de baldíos otorgadas a particulares si no las roturaban en breve plazo(145).

En todo caso, suponiendo que la concesión de 1624 continuara vigente, convenía legalizarla de un modo más adecuado para disipar posiles dudas acerca de quién había de ser el usufructario de tales terrenos. Es por ello que, en 1633, tras haber facilitado un nuevo crédito a la ciudad ${ }^{(146)}$, D. Jerónimo volviera a solicitar de nuevo el mismo territorio pero, en esta ocasión, mediante establecimiento enfitéutico y ofreciendo la promesa de «panificarlo» ${ }^{(147)}$.

Por una vez, los jurados, que no podían denegar el favor, insistirían en dejar bien claro los términos en que se produciría lo que, a efectos reales, no dejaba de ser una privatización. Concretamente, habría de respetarse el mantenimiento de su condición realenga, recogido en la cláusula siguiente:

«Primo que lo dit D. Geroni Rocamora ni los suos per nengú ni de present aleguen ne puguen alegar que dites terres saladars establides $a b$ lo present són de sa jurisdictió y terme en lo dit lloch de La Pobla nech aliis ans bé que aquelles resten com hui y ajen de restar y ser sempre del terme y jurisdicció de la present Ciutat com al present o són $\gg^{(148)}$. 
En caso contrario se incurriría en pena de comiso, consolidando la ciudad ambos dominios «per a podre dispondre de aquelles a sa voluntat».

Por otro lado, se autorizaba a D. Jerónimo - quien sólo había de pagar un censo anual de 5 libras - para, a su vez,

«repartir dites terres establides entre los vehins y habitadors del dit lloch de la Pobla en la forma que els pareguera sens tenir obligació de demanar llisènsia alguna a la Ciutat ni pagar lloisme algú per rahó de dita repartició».

Por parte de la ciudad se trataba, pues, de facilitar el proceso roturador encomendado su iniciativa a alguien con capacidad financiera suficiente para emprender las obras de acondicionamiento; o, al menos, tales eran sus argumentos: «y així la dita Ciutat no reb profit ne utilitat alguna en ninguna manera y per consegüent no se a tret de aquella fruit algú perque són terres infrustíferes de manera tal que es inposible a la dita Ciutat o al menys molt dificultós y costós poder reduhir dits saladars a cultura y si aquells se procurasen podria ser que donasen profit principalment estant en poder de perçona poderosa que no reparàs en lo gasto».

De este modo,

«no sols redundarà en benefici de la Ciutat collint-se fruïts sinó també en benefici del delme y primícia hoc y encara causarà sanitat en aquelles partides $a b$ la dita reductió a cultura dels dits saladars per altre nom almarjals».

Pero, apesar de tan felices perspectivas, las condiciones del establecimiento no parece que llegaran a cumplirse. Para que la bonificación de tales terrenos hubiera constituido una empresa rentable, siquiera a medio plazo, se requerían como mínimo dos presupuestos básicos. En primer lugar, la imposibilidad efectiva de acceder a tierras de mejor calidad a un coste unitario no superior al que aquella exigía; circunstancia que, en la coyuntura de entonces, estaba lejos de haberse alcanzado en el Bajo Segura. En segundo término, la inexistencia de usos productivos alternativos para dichos saladares, condición que tampoco concurría en este caso. En consecuencia, D. Jerónimo se abstendría de cumplir la promesa contraída con los jurados de Orihuela, prefiriendo destinar el terreno al apacentamiento de su extensa cabaña ganadera o a la recolección de la sosa ${ }^{(149)}$.

Sólo unas décadas más tarde, en 1700 , la ciudad, inmersa en un proceso de recuperación de dehesas particulares, reclamaría estos terrenos alegando dos motivos fundamentales: el ejercicio de la jurisdicción sobre dicho establecimiento por parte del justicia de La Puebla y el impedimento que se hacía a los vecinos de Orihuela de «herbajar, fer lenya, arrancar pedra e demés amprius» ${ }^{(150)}$. Pero habría de ser finalmente, a instancias del cardenal Belluga, cuando culminaria su expropiación, incorporando el antiguo establecimiento en las Pías Fundaciones ${ }^{(15)}$.

Según las alegaciones de posteriores sucesores de D. Jerónimo, en realidad, los marjales contiguos a la baronía de La Puebla poseídos por nuestro hombre no se reducían meramente a los ya mencionados. Por el contrario, también habría detentado en dominio absoluto otras 2.400 tahúllas, aparte de las 2.000 que componían el establecimiento de la ciudad, incorporadas a todos los efectos en el tér- 
mino propio de la baronía. Se trataban de dos lotes de 2.000 y 400 tahúllas, adquiridas respectivamente «con título de venta y remate judicial» en $1627^{(152)}$ y por transferencia con cargo a una deuda a que era acreedor, en 1631, a sendos particulares $^{(153)}$. De nuevo, he aquí las dos fórmulas privilegiadas de acceso a la propiedad.

En consecuencia, parece claro el interés de D. Jerónimo por anexionarse terrenos baldíoss, colindantes al núcleo primitivo de la baronía, con tal de ampliar los límites territoriales sometidos a su jurisdicción. Aunque su puesta en cultivo resultase aún problemática, los usos alternativos que proporcionaban constituían otra fuente de recursos nada despreciable. Pero, además, su discutida transformación en propiedad señorial permitía un mayor control sobre el territorio, imprescindible para hacer valer sus derechos exclusivos.

\subsection{El señorío y marquesado de Rafal}

Siguiendo la trayectoria señalada hasta el momento, la adquisición y repoblación de Rafal constituye un nuevo éxito en su profusa actividad señorial. Las expectativas que las fórmulas recientemente ensayadas ofrecían de cara a rentabilizar del modo más adecuado sus inversiones agrarias determinarían en gran parte la actitud que venimos observando.

Tampoco en el caso de Rafal resultará imprecindible remontarse a la evolución seguida por el contenido real del topónimo, desde su primitiva configuración como núcleo de importante asentamiento humano dependiente de Orihuela, hasta su posterior despoblación ${ }^{(154)}$. Pero sí conviene indicar, a grandes rasgos, cual era su situación en las décadas inmediatamente anteriores a su adquisición por D. Jerónimo, como elemento de contraste para valorar la acción emprendida.

En 1583, sin ir más lejos, su titular, Mosén Gaspar García de Laza, la describía como

«una heretat apel.lada Rafal de mil tafulles de terra poc més o menys ab dos casses en aquella ensemps ab la senyoria y terratges pertanyents a la senyoria de Rafal en les terres establides a diversos particulars a responsió de cinch cafisos de forment per centenar cascun any que són tots los dits cafisos qués responen a dita senyoria per la dita rahó setanta cafisos poc més o menys cascun any de forment $e$ tota altra directa senyoria que a mi pertany sobre les dites tafulles»(155).

A tenor de esta descripción ha de establecerse una clara distinción entre la heredad, por una parte, y la señoría por otra, como elementos diferenciados y no coincidentes, ni tan siquiera yuxtapuestos. La heredad correspondía al territorio no establecido, reservándose el término señoría para designar las tierras censidas, en clara alusión al dominio directo ejercido sobre ellas.

A primera vista, la existencia de estos establecimientos podría sugerir un proceso de colonización anterior, frustrado o no en la medida en que hubiera logrado desembocar en la constitución de un vecindario con la entidad suficiente para permitir al señor directo la adquisición de la jurisdicción alfonsina y su pos- 
terior conservación. Parece difícil, no obstante, aceptar tal posibilidad, por cuanto las condiciones en que fueron realizados los establecimientos, tiempo atrás, en modo alguno apuntaban en esa dirección repobladora.

Según se desprende del contenido de tres establecimientos fechados en 1499, se trataría más bien de asegurar únicamente el cultivo de la tierra y la percepción de una renta fija pagadera en trigo, desentendiéndose por completo el señor directo de otras cuestiones. Así, en ningún caso se alude a la obligación de residencia del censatario, a quien se otorgaba, además, facultad para «fer crida... e clamar-se dels que sentraran com a cosa sua pròpia sens demanar llicènsia" y para «arrancar e plantar arbres en la dita heretat e mudar rechs, e scorredors, e obrar, e derrocar a son beneplàsit». Por otra parte, los lotes cedidos eran de 100 y 200 tahúllas y sus beneficiarios labradores y ciudadanos avecindados en municipios realengos del entorno, sin relación alguna de vasallaje ${ }^{(156)}$.

En consecuencia, independientemente de lo que hubiese llegado a ser en sus primeros tiempos tras la conquista, durante el siglo XV Rafal se había convertido básicamente en una heredad cuyos propietarios - los García de Lasa- detentaban, además, la señoría directa sobre tierras anexas a ella. Tampoco debía contar con término propio que pudiese haberla dotado de cierta entidad territorial, puesto que algunas parcelas serían incluidas posteriormente en los términos de Callosa y Orihuela; y, por supuesto, no existían pobladores al estar avencindados los censatarios en otros municipios. Tal y como expresaba un testimonio de 1582, Rafal era por entonces «una heretat ab una casa y alrrededor de aquella y ha altres terres ab cases les quals terres son tributàries a la dita casa de Rafal» ${ }^{(157)}$.

Pero veamos a continuación cómo consiguió $\mathrm{D}$. Jerónimo alzarse con la titularidad de este valioso patrimonio y los cambios introducidos.

El último sucesor por línea masculina de la heredad y señoría directa de Rafal había sido Mosén Gaspar García de Lasa quien, al fallecer sin hijos varones, legó sus posesiones a su primgénta, D. ${ }^{a}$ Ana, con obligación de restituir a su otra hija, D. ${ }^{a}$ María, 5.000 libras en concepto de dote para su matrimonio ${ }^{(158)}$. En 1611 , con ocasión de los esponsales contraídos con D. Jerónimno, D. ${ }^{a}$ María reclamaría de su hermana la parte de su herencia, tal y como había sido dispuesto. Entre otros bienes, se le haría donación, en 1621, del usufructo vitalicio.

«de la mitat de la heretat apel.lada de Rafal que són dos parells de terra, de aquelles quatre parells que ay en dita heretat... ab pacte y condició que en dita heretat de Rafal que li dona no se haja de entendre ni entenga lo dret de terrage que se li respon a dita señora de Rafaly)(159).

Quedaba claro, por tanto, cual era la parte que había de corresponderle y cual la que se reservaba la heredera. En 1622, sin embargo, fallecia D. ${ }^{a}$ Ana intestada y sin haber dejado descendencia, iniciándose a partir de entonces las correspondientes acciones ante los tribunales por parte de los pretendientes a la heredad y señoría directa de Rafal. Dos fueron los que concurrieron para hacer valer sus derechos: D. Jerónimo Rocamora, como procurador y esposo de D. ${ }^{\mathrm{a}} \mathrm{Ma}$ ría, y D. Juan Ferrer de Proxita, anterior marido de la difunta y a la sazón casado en segundas nupcias con D. ${ }^{a}$ Leonor García de Lasa, hermana de D. Gaspar -su anterior suegro-. 
Aunque en $1623 \mathrm{D}$. Jerónimo se apresuraba a tomar posesión de Rafal ante el justicia civil de Orihuela, en cumplimiento de una sentencia favorable, poco después era $\mathrm{D}$. Juan quien la obtenía a su favor, prolongádose las sucesivas instancias y apelaciones ante diversos tribunales ${ }^{(160)}$. Finalmente, a principios de 1626, ambas partes llegaban a un acuerdo, mediante concordia, para evitar más gastos originados por los pleitos y decidir el destino de la herencia de forma definitiva. Como era de prever, D. Jerónimo no iba a dejar perder la oportunidad de obtener el patrimonio en disputa, aunque tuviese que ceder algo a cambio ${ }^{(161)}$.

En virtud de la concordia firmada, D. Juan Ferrer renunciaba a cualquier derecho y pretensión sobre la heredad y señoría de Rafal a favor de su rival. En compensación, D. Jerónimo quedaba obligado a satisfacerle una cantidad anual de 190 libras durante su vida, al tiempo que le eximía de la restitución de los bienes muebles aportados por $D .^{a}$ Ana al matrimonio, valorados en 1.000 libras. Mediante esta transacción Rocamora conseguía añadir a su ya importante patrimonio una nueva propiedad que más tarde convertiría en núcleo de marquesado. El juego de alianzas matrimoniales practicado había dado, en este caso, mayores resultados que los que posiblemente él mismo hubiese esperado.

Aunque tampoco en este caso son exhaustivas las referencias documentales que he podido localizar acerca de la inmediata organización de la nueva adquisi. ción, al menos si es posible realizar mayores precisiones. En primer lugar, conviene destacar la labor colonizadora llevada a cabo estableciendo casas y tierras en enfiteusis entre un número de pobladores suficiente para adquirir la jurisidcción alfonsina y formar un lloch con propia entidad municipal. Es difícil conocer la fecha exacta de estos primeros establecimientos, pero al poco tiempo de la muerte de D. Jerónimo, su viuda inventariaba en Rafal un total de 18 casas, iglesia en construcción, regalías de tienda, taberna, panadería, horno y carnicería, así como la señoría directa de las tierras y casas establecidas a censo enfitéutico a los vasallos. A todo ello se añadía la antigua señoría directa correspondiente a los tradicionales establecimientos que poseían los censatarios forasteros ${ }^{(162)}$.

Es imposible conocer el contenido exacto de estos nuevos establecimientos de Rafal puesto que ya en 1643 se habian extraviado y fue necesario redactarlos de nuevo, pero ha de suponerse que no debieron ser excesivamente diferentes de estos últimos, otorgados por su hijo D. Gaspar

«sens derrogació de altre acte de establiment de aquelles fet per lo il.lustre quondam Don Hieroni Rocamora Marqués de Rafal pare de dit Don Gaspar... lo qual e dit acte per ser mort Ginés Martines notari rebedor de aquell no es troba ans bé a major corroboració de dit primer establiment los fa $\mathrm{ab}$ los pactes y condicions següents.... $)^{(163)}$.

En realidad, pese a tratarse de establecimientos individuales pueden considerarse como carta-puebla de Rafal, ya que en los 24 capítulos que contiene cada escritura quedarían reguladas todo tipo de relaciones señoriales, particulares y colectivas - como miembros de la comunidad vecinal-, así como las que conciernen a la administración municipal. No es este el momento de extenderse en su análisis pormenorizado, pero sí conviene adelantar algunos de sus aspectos más relevantes. 
Si hemos de suponer, por tanto, que las condiciones de 1643 no habrían de diferir sustancialmente de las originales, los lotes establecidos habrían oscilado en torno a las 30 tahúllas de huerta, en su mayoría tierra blanca -alrededor de un $70 \%-$ y el resto viña y moreral. En consecuencia, tratábanse de explotaciones que, merced a su extesión y distribución de cultivos, podían adecuarse en un principio a las necesidades del núcleo familiar. El censo estipulado, consistente en 9 sueldos por tahúlla con independencia del tipo de cultivo, no era excesivamente gravoso en comparación con los vigentes en otros señoríos del entorno y, en todo caso ha de ser considerado como atractivo para el enfiteuta ${ }^{(164)}$. Las casas, por su parte, quedaban gravadas en 20 sueldos y una gallina anual, además de un tercio de su valor por derecho de entrada. Otros capítulos hacían referencia a los derechos jurisdiccionales del señor, vasallaje, utilización de regalías, etc., establciéndose igualmente la constitución de municipio con sus justicia y jurados, que serían nombrados anualmente por el señor de una terna presentada por los vasallos.

De este modo, la antigua heredad de Rafal se transformaba en señorío alfonsino. He de insistir una vez más en la importancia de conocer la fecha exacta de este acontecimiento para valorar el sentido de la petición elevada en 1636 por D. Jerónimo, solicitando el título de marqués y el mero y mixto imperio sobre Rafal. Pues, de haber sido posteriores los establecimientos mencionados, hubieran significado una estrategia forzada para obtener al menos la condición señorial contemplada en el fuero de 1329 , toda vez que la suprema jurisdicción le sería denegada - aunque no el título de marqués-(165).

De cualquier forma, no conviene olvidar que sólo una parte de las tierras de Rafal sería cedida a los vasallos $(160)$. La estrategia señorial, al igual que en el caso de Benferri e incluso La Puebla, habría intentado conjugar el asentamiento efectivo de la población con la reserva de una proporción del territorio en dominio absoluto del señor. En la medida en que ambas facetas no entrasen en conflicto, la colonización señorial podía resultar un éxito. No importaba que el señor tuviese que desprenderse, en un principio, del dominio útil de algunas parcelas -siempre recuperables merced al derecho de fadiga y comiso- si ésta era la única vía que podía garantizar el avecindamiento y vasallaje efectivo de los colonos.

Sobre la importancia concedida a la residencia en el lugar, como factor clave para el mejor cuidado de la tierra, amén de los beneficios que deparaban la utilización de las regalias y los emanantes de la relación vasallática, es bastante elocuente la prohibición de enajenar el dominio útil a forasteros. Y, sobre todo, la disposición según la cual si

«alguns de aquells mudaran son domicili y alberch a altra part fora del dit lloch y per dita rahó les dites casa y tafulles que ab lo present les són establides vindran a meins que pujen ser compel.lits per dit il.lustre Marqués a que vinguen a viure y habitar al dit e present lloch de Rafal y a conrrear y a sustentar les dites casa y tafulles que tindran $»^{(167)}$.

Si la obligación de residencia se configuraba como un elemento fundamental en la empresa señorial, la pervivencia de los tradicionales censatarios forasteros no podía encajar muy bien en el modelo concebido. Es por ello que, paralelamen- 
te a la acción colonizadora emprendida en la heredad — núcleo de la reciente fundación- D. Jerónimo hiciera cabrevar e iniciara causas de comiso contra los vecinos de Orihuela y Callosa que disponían de aquellos establecimientos «que antiguament es nomenaven terrajes» ${ }^{(168)}$.

Podría entenderse esto como un intento por recuperar, en la medida de lo posible, el dominio útil de aquellas tierras que habían constituido la señoría directa de Rafal y cuyo beneficio quedaba reducido a la mera percepción de una renta ${ }^{(169)}$. La preocupación por consolidar el dominio absoluto de la tierra podía ser compatible, de este modo, con la colonización señorial. En realidad, ambos elementos eran los que definían su estrategia señorial.

Sin embargo, D. Jerónimo habría de dejar este mundo sin haber conseguido enteramente su propósito. Y tampoco parece que sus herederos persistieran demasiado en ello, puesto que en un inventario de 1645 aún se mencionaban, entre las tierras comprendidas en el marquesado de Rafal, las «establides als pobladors de dit lloch y a moltes altres persones de la present Ciutat vila de Callosa y altres llochs $)^{(170)}$. Las dificultades legales para despojar a estos enfiteutas forasteros del dominio útil de la tierra explicarían su permanencia, aunque también es posible que se llegaran a establecer cierto tipo de compromisos.

Concretamente, a los pocos días de la muerte de D. Jerónimo, su viuda volvía a establecer a un vecino de Callosa 16 tahúllas de viña con algunos frutales por el mismo canon en trigo que venía pagando antes de que le hubieran sido comisadas. Sólo que, por razón del nuevo establecimiento, el mismo enfiteuta había de satisfacer ahora 10 libras $^{(171)}$. Se trataba, evidentemente, de una vía intermedia entre el despojo definitivo por comiso y la continuidad sin más en la posesión del dominio útil bajo las mismas condiciones anteriores. De esta forma, aquellos que habiendo incurrido en comiso, no pudieran -o quisieran - abonar este nuevo derecho de entrada por una tierra que ya venían cultivando, permitirían la consolidación de dominios en manos del señor. Con todo, he de indicar que constituye el único caso que conozco sobre establecimiento de tierras comisadas al mismo que las poseía, por lo que quizás no represente la tónica general.

\subsection{Propiedad realenga}

Si la propiedad señorial de la tierra constituyó la modalidad preferida por Rocamora en relación a las explotaciones agrarias, la posibilidad de ir acumulando pequeñas pero valiosas parcelas realengas tampoco habría de quedar enteramente marginada. No en vano, la consolidación de un importante patrimonio agrario, de cualquier índole que fuese, siempre sería su objetivo primordial.

Cuando, en el codicilo de 1634, legaba a uno de sus herederos los créditos sobre la ciudad de Orihuela, evaluados en 25.000 libras, estipulaba una condición muy precisa para ello; «ab gravame que les dites quantitats les haja de anar comersant y empleant en comprar tafulles» ${ }^{(172)}$. Expresión que define claramente cual debía ser el destino final de los activos de capital financiero y comercial acumulado.

El propio D. Jerónimo, a lo largo de su vida, habría de contar con sobradas ocasiones para poner en práctica tales intenciones. Algunos ejemplos de ello ya- 
han sido mencionados al tratar sobre su actividad señorial, pero no todas sus adquisiciones podían seguir, evidementemente, el mismo destino, permaneciendo en su condición realenga.

Aunque a partir de los datos disponibles no es posible trazar con detalle el ritmo exacto de adquisiciones, si que pueden conocerse las que detentaba al final de sus días, tal y como refleja el cuadro siguiente:

CUADRO V

\begin{tabular}{|c|c|c|c|c|}
\hline Núm. tahúilas & Calidad & Cultivo & $\begin{array}{l}\text { Forma de } \\
\text { adquisición }\end{array}$ & Ubicación \\
\hline $\begin{array}{c}200 \text { (Heredad } \\
\text { Era Alta }\end{array}$ & huerta & blanca-viña- & compra «per cort» & $\begin{array}{l}\text { limite con } \\
\text { La Puebla }\end{array}$ \\
\hline $\begin{array}{l}330 \text { (Heredad } \\
\text { de Tell) }\end{array}$ & huerta & $\begin{array}{l}\text { blanca-viña- } \\
\text { moreral }\end{array}$ & dote de su esposa & $\begin{array}{l}\text { límite con } \\
\text { Rafal }\end{array}$ \\
\hline $\begin{array}{l}65 \text { (Heredad } \\
\text { Pta. Murcia }\end{array}$ & huerta & $\begin{array}{l}\text { blanca-viña- } \\
\text { morer-frutal }\end{array}$ & compra s. e. & $\begin{array}{l}\text { Puerta de } \\
\text { Murcia }\end{array}$ \\
\hline 17 & huerta & moreral & compra «per cort» & Ac. Moquita \\
\hline 20 & huerta & moreral & compra «per cort» & Ac. Huertos \\
\hline 8 & huerta & moreral & «renunciació» & Guardalacapa \\
\hline 10 & huerta & moreral & $\begin{array}{l}\text { liquidación de } \\
\text { deudas }\end{array}$ & Ac. Huertos \\
\hline 8 & huerta & moreral & compra s. e. & Ac. Huertos \\
\hline 13 & huerta & moreral & compra s. e. & Ac. Huertos \\
\hline 15 & huerta & moreral & compra «per cort»» & Ac. Huertos \\
\hline 15 & huerta & $\begin{array}{l}\text { moreral- } \\
\text {-blanca }\end{array}$ & compra «per cort»» & Bonanza \\
\hline 72 & huerta & blanca & compra s.e. & Correntías \\
\hline
\end{tabular}

773 thas. total huerta

1 Cañada campo blanca compra s.e. Salinas

Fuente: Inventario de 1639

Además de las mencionadas, D. Jerónimo llegó a comprar otras parcelas cuyo destino posterior ignoro, toda vez que ya no figuraban en el inventario de 1639. Es el caso, por ejemplo, de las 210 tahúllas de tierra blanca, viña y moreral adquiridas en Catral por escritura de compra de $1634^{(173)}$.

A excepción de la heredad de Tell, que llevó su segunda esposa al matrimonio, el resto fueron adquiridas en vida de Rocamora en su totalidad, aunque no siempre mediante el desembolso efectivo de su precio real. En los casos más frecuentes, se trataba de ventas ejecutivas realizadas por los tribunales competentes y adjudicadas a su favor por un valor normalmente inferior al estimado. Cuando, por acumulación de la deuda e insolvencia manifiesta para hacer frente a ella, los bienes de los afectados hubieron de entrar en el mercado de tierras de forma forzosa bajo el peso de los acreedores, aquellos que disponían de efectivos y estaban realmente interesados en su apropiación disponían de inmejorables condicio- 
nes para adquirir a buen precio lotes que, en circunstancias normales, hubieran precisado un mayor desembolso. Posiblemente, incluso, el acreedor real en estos casos de venta «per cort» fuese el propio D. Jerónimo.

En dos ocasiones, la transacción reflejaba claramente la liquidación de una deuda mediante acuerdo entre las partes, sin necesidad de recurrir a la vía judicial; circunstancia que, lógicamente, debía incidir sobre los términos del intercambio, devaluando el precio de la tierra. El reintegro de la deuda en propiedades agrarias refleja de nuevo cómo la intensa actividad desplegada por D. Jerónimo como prestamista, comerciante y especulador estaba en la base de la formación de su patrimonio territorial.

No ha de creerse, sin embargo, que eran siempre los pequeños campesinos quienes sufrían las nefastas consecuencias de estas expropiaciones, puesto que en algunos de los casos analizados aparecen determinados miembros de la oligarquía ciudadana que tampoco pudieron librarse de las redes echadas por D. Jerónimo(174).

Por otro lado, resultaba elocuente su preferencia por las parcelas de huerta en relación a las ubicadas en el secano, dada la superior calidad de la tierra y la posibilidad de extraerle mayores rendimientos a sus cultivos. A título indicativo, basta añadir que, en los casos conocidos, la parcela de moreral solía alcanzar y aún sobrepasar las 50 libras por tahúlla de valor, por lo que, pese a tratarse de lotes más bien pequeños, resultaban sumamente estimables ${ }^{(175)}$.

En cuanto al régimen de explotación empleado, no es mucho lo que puede afirmarse de modo concluyente. El escaso número de escrituras de arrendamiento localizadas ${ }^{(176)}$ permite aventurar que, al menos los morerales, debieron ser cultivados en buena parte por cuenta propia, aunque no cabe descartar la posible incidencia de ocasionales contratos verbales de arrendamiento por un año(177). Incluso en ciertas ocasiones es posible encontrar a D. Jerónimo tomando tierras ajenas "a miges» - aparcería- ${ }^{(178)}$ o bien morerales en arrendamiento ${ }^{(179)}$ para su explotación a través de labradores. La diversidad y simultaneidad de formas de explotación a que solía recurrir impide, por tanto, que pueda pronunciarme sobre la fórmula mayoritariamente adoptada. Pero, en todo caso, merece destacarse su decidida intervención en la comercialización directa de las cosechas producidas en sus patrimonios. No se trataba tanto de asegurar el cobro de una renta, desentendiéndose de lo demás, como de aprovechar los beneficios comerciales que deparaba el control de la producción.

\subsection{Comercialización de productos agrarios}

El especial interés por adjudicarse esas pequeñas explotaciones dispersas por la huerta radicaba, evidentemente, en su exclusiva dedicación al monocultivo de la morera. Este hecho, bastante sintomático de cuales eran sus cosechas preferidas, inducen a pensar, en principio, en posibles vinculaciones de D. Jerónimo con el proceso de elaboración primera o el comercio de la seda. Y, efectivamente, no es casual este predominio de morerales en la parcelas que acabaría adquiriendo, puesto que según se desprende de ciertos datos aislados, pero suficientes, su actividad como comerciante de seda debió ser bastante considerable. 
En 1631, D. Jerónimo otorgaba poder a un mercader de Córdoba para vender en su nombre 245 libras de peso de seda redonda, cantidad en modo alguno despreciable ${ }^{(180)}$. Al mismo tiempo, muchas de las obligaciones y deudas monetarias a que era acreedor, así como el precio de otras transaciones y arrendamientos realizados, eran cobrados frecuentemente en seda ${ }^{(181)}$; ha de suponerse que a precios ventajosos para nuestro hombre, quien volvía a negociar con ella. Pero además, también solía efectuar frecuentes compras de «fulla per a criar llavors de cuchs") a pequeños cosecheros locales, fijando los precios con antelación a la cosecha y pagando al contado, cuando no se trataba de cancelación de obligación anterior ${ }^{(182)}$. Por último, cabría añadir que en algunas de sus parcelas y heredades disponía de «barraca per a criar seda»e incluso de "palau y filador» (183).

Si la comercialización de la seda debió reportarle sustanciosos beneficios, máxime contando con agentes en los centros manufactureros, el extenso patrimonio que consiguió reunir le situó muy pronto como uno de los principales cosecheros de la comarca en diversos productos agrarios. Así, el secuestro del trigo ordenado por lo jurados de 1628 , para la huerta de Orihuela, contabilizó en las cuatro heras de D. Jerónimo -excluida la de Benferri y la cañada de Salinasun total de 930 cahíces, ocupando con ello el primer lugar entre los grandes productores ${ }^{(184)}$.

Buena parte del grano cosechado en sus dominios habría de contar con un mercado seguro en la propia ciudad de Orihuela, en cuya cambra o pósito conseguía introducir cada año ingentes cantidades; especialmente a partir de 1625 , en que fueron modificados los estatutos para su administración, destacando como uno de los principales abastecedores locales ${ }^{(185)}$.

\section{CUADRO VI}

Trigo vendido al pósito de Orihuela

\begin{tabular}{|c|c|c|}
\hline Año agrícola & Cantidad & N. ${ }^{\circ}$ de orden \\
\hline $1625-26$ & 264 cahíces & $3 .^{\circ}$ vendedor \\
\hline $1626-27$ & 50 cahíces & $5 .^{\circ}$ vendedor \\
\hline $1628-29$ & 200 cahíces & $1 .^{\circ}$ vendedor \\
\hline $1630-31$ & 100 cahíces & $2 .^{\circ}$ vendedor \\
\hline $1634-35$ & 400 cahíces & $3 .^{\circ}$ vendedor \\
\hline $1635-36$ & 350 cahíces & $1 .^{\circ}$ vendedor \\
\hline $1637-38$ & 47 cahíces & $6 .^{\circ}$ vendedor \\
\hline
\end{tabular}

Fuente: AMO: Libros del Pósito (de los años reseñados)

Otras veces, cuando el pósito tenía que recurrir al trigo castellano para completar su provisión anual - como habría de ocurrir durante el invierno de 1626D. Jerónimo sería el encargado de realizar la labor de intermediario, merced a sus contactos con carreteros foráneos ${ }^{(186)}$. Pero, además de estas ventas, también solía actuar en los momentos de la siembra como prestamista de trigo, tanto a particulares como a graneros colectivos, para su restitución al tiempo de la cosecha con el aumento correspondiente a la diferencia de precio ${ }^{(187)}$. 
También el vino, el aceite y el arroz constituían productos agrícolas a cuya producción y comercialización no era ajeno Rocamora. Con respecto al vino, su intervención alcanzaría a los dos aspectos mencionados. El cultivo de la vid no estuvo ausente de sus heredades de realengo, pero tampoco llegaría a alcanzar una considerable difusión, quizás por su tendencia a diversificar el destino de sus inversiones. Aún así, en la denominada heredad de la Puerta de Murcia, los jurados de 1603 hallaron un total de 100 cántaros de vino y en la vecina heredad de Bonanza - por entonces a su cargo- se contabilizaron hasta $800^{(188)}$. En la Era Alta, también había viñas y bodega, al igual que en la de Tell, pero en esta última fue el propio D. Jerónimo quien hubo de introducir el cultivo en 1618-19, comprometiéndose a plantar a sus costas un total de 60 tahúllas ${ }^{(189)}$. También a aquí dispuso de bodega, al igual que en la casa señorial de Rafal, donde acudían a llevar el vino los vasallos del lugar ${ }^{(190)}$.

A su condición de propietario de viñas hay que añadir también su participación en la comercialización del vino, y ya no sólo en lo que se refiere a los excedentes de sus propias cosechas. En 1627, por ejemplo, aceptaba una partida de 1.000 cántaros ofrecida por un mercader oriolano en pago de una deuda de 3.000 reales ${ }^{(191)}$; y unos días antes, había comprado otros 300 cántaros a uno de sus principales deudores al significativo precio de un real por unidad ${ }^{(191) \text { bis })}$.

Operaciones comerciales de este tipo, orientadas en su mayor parte a su reventa posterior, venían propiciadas de nuevo por su favorable posición de acreedor.

El aceite, en cambio, procedía del señorío de Benferri, plantado de olivar en buena parte y provisto de almazara ya desde antes de su colonización ${ }^{(192)}$. En cuanto al arroz, posiblemente fuera cosechado en la baronía de la Puebla y almarjales contiguos. Las pocas referencias que conozco sobre el particular, relativas a ciertas ventas efectuadas en 1631 - una de ellas en cantidad de 1.000 arrobas- ${ }^{(193)}$ también podrían indicar que se trataba de operaciones de reventa.

$\mathrm{La}$ intervención de $\mathrm{D}$. Jerónimo en otras operaciones, como el subarrendamiento o teneduría de los frutos y rentas pertenecientes al obispado de Orihuela ${ }^{(194)}$ o a la administración de heredades, como tutor de menores ${ }^{(195)}$, también debió proporcionarle nuevas oportunidades de ampliar aún más sus ya diversificadas fuentes de recursos.

\section{D. Jerónimo, ganadero}

En el terreno que ahora nos ocupa, el predominio de D. Jerónimo no iba a ser menor, llegando a convertirse muy pronto en el mayor propietario de ganado mayor del Bajo Segura. Posteriormente, su condición de primer ganadero aún se incrementaria, haciéndose extensible al ganado menor. Las cifras referidas a continuación, que excluyen los animales de labor existentes en sus heredades y señoríos, reflejan su composición, al tiempo que constituyen un valioso indicativo de su tendencia expansionista.

Tanto la yeguada como la vaquería tenían como finalidad primordial la crianza de animales de labor utilizados en el entorno, aunque también podian ser destinados - caso del vacuno- a la alimentación e incluso, eventualmente, a su 


\section{CUADRO VII}

Existencias en ganado

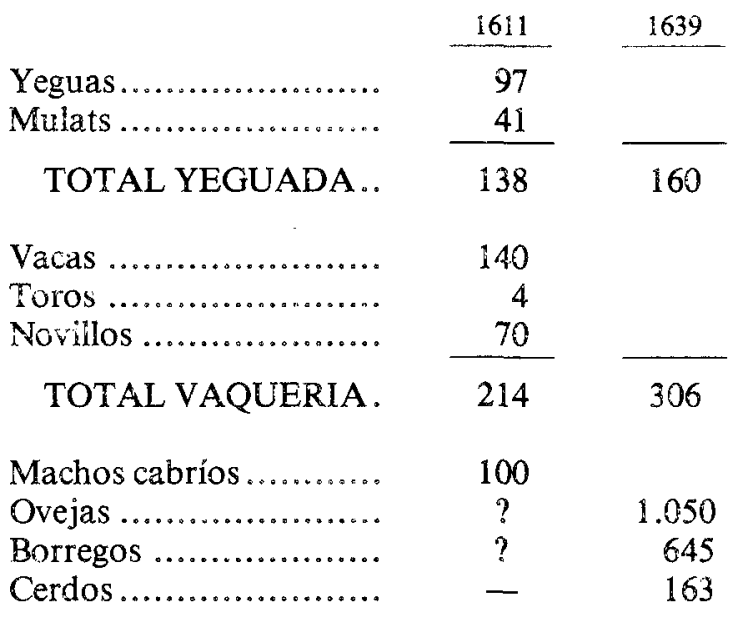

Fuentes: Inventaries de 1611 y 1639

alquiler para las corridas de toros ${ }^{(196)}$. En realidad, tal y como sugieren las innumerables escrituras recogidas en los protocolos notariales, D. Jerónimo representaba sin duda alguna el principal abastecedor de este tipo de ganado especialmente solicitado para las labores agrícolas, actividad que no sólo le proporcionaba ingresos considerables, sino también una estrecha vinculación comercial con los labradores que precisaban de tracción animal para el cultivo de sus tierras y con los arrieros y carreteros.

Estas relaciones solian establecerse mediante las consabidas obligaciones, cuando el comprador no podía hacer efectivo de inmediato el valor de la adquisición, comprometiéndose a efectuar el pago en un futuro no excesivamente lejano.

Orientación exclusivamente alimentaria tenía, en cambio, el ganado porcino $\mathrm{y}$, a semejanza de los anteriores, también contaba con abundantes hembras de cría para ir reponiendo y aumentando sus efectivos conforme iban siendo comercializados. En algunas ocasiones, su explotación no era realizada directamente a través de mayorales - como era habitual - sino encomendada a terceras personas, durante períodos de tiempo limitado, quedando a cargo de éstos los gastos de alimentación, pastoreo y custodia y cualquier otro que pudiese surgir - acondicionamiento de zahúrdas, etc. - a cambio de una participación en los beneficios ${ }^{(197)}$.

Con respecto a la crianza de cabrío y bovino merece destacarse el protagonismo de D. Jerónimo como abastecedor de Orihuela, tomando repetidamente a su cargo el suministro de las carnicerías. Este monopolio municipal solía ser subastado públiamente al alza por los jurados, quedando obligado el mejor postor 
a proporcionar la carne necesaria al precio estipulado en el remate. El abastecedor obtenía el libre uso de los «bovalares» y la libre disposición de lanas y pieles para su comercialización.

$\mathrm{El}$ interés que D. Jerónimo mostrara hacia este posible negocio también habría de quedar plenamente de manfiesto, consiguiendo adjudicarse casi todos los años dicho abastecimiento, bien en nombre propio, bien a través de agentes o testaferros que actuaban en su nombre ${ }^{(198)}$. En algunas ocasiones, una vez conseguido el remate a su favor, podía entrar en contacto con otros individuos asimismo interesados en vender su carne en Orihuela, lo que abría la posibilidad de realizar ciertas especulaciones ${ }^{(199)}$. Si a todo ello añadimos el trato de favor que solían recibir las ofertas de D. Jerónimo por parte de los jurados de la ciudad, se comprenderán perfectamente las oportunidades que ofrecía este campo de inversión. A las ganancias obtenidas de la carne se añadían, además, las procedentes de la comercialización de los menudos, pieles y lanas ${ }^{(200)}$.

Para el apacentamiento y pastoreo de su extensa cabaña, contaba Rocamora con varios mayorales que llevaban el ganado a las dehesas señoriales, a las redondas y realengos del término de Orihuela, a los bovalares - en cuanto lo permitía su condición de abastecedor-e incluso al vecino término de Murcia durante las horas de sol, en virtud de cierta mancomunidad de pastos acordada entre ambas ciudades.

A todas las formas de aprovechamento anteriormente aludidas habría que añadir, lógicamente, las que deparaba la utilización del fertilizante animal.

\section{Una mentalidad de transición}

El creciente protagonismo que, día a día, iba adquiriendo nuestro hombre en el ámbito de las relaciones económicas pronto llegaría a convertirle en una de las personalidades más influyentes de la comarca. Acusaciones de parcialidad contra los administradores de justicia «per complaure al dit Don Gerony per ser persona tan poderosa en aquelles terres» ${ }^{(201)}$ no eran infrecuentes; y el mero hecho de haber colocado su escudo de armas en la casa del pósito de la ciudad constituía un signo más que evidente de su poderío(202).

Pero una prepotencia de este tipo no podía descansar únicamente en el control de los resortes económicos, sino que precisaba además de un reconocimiento público a través del desempeño de importantes cargos político-administrativos y de una preeminencia social garantizada por una escalada nobiliaria en toda regla. Y, ciertamente, la extremada preocupación que siempre mostrara D. Jerónimo por el más cercano seguimieno y la gestión directa de sus negocios, jamás abandonados, en modo alguno habría de suponer una desatención de estas otras parcelas mencionadas.

Para aquellos que, como él, habían antepuesto el mérito personal a los ya marchitos valores de una vieja y parasitaria aristocracia de sangre, el aparato de la monarquía tenía bastante que ofrecer. Sobre todo si, además, la posesión de un rancio y glorioso apellido figuraba como complemento de esa valía personal. No ha de extrañar, por tanto, que en 1626 obtuviese el cargo de Lugarteniente del Gobernador de Orihuela, que llegaría a desempeñar por el resto de sus días ${ }^{(203)}$. 
Amén de su intrínseca dimensión política, el control del poder judicial que este oficio comportaba, dadas las frecuentes ausencias del titular de la Gobernación, lo hacía doblemente apetecible para aquellos que mantenían no pocos intereses - con las inevitables situaciones conflictivas que podían suscitarse-en el ámbito territorial sometido a su jurisdicción.

Pero las ambiciones de $\mathrm{D}$. Jerónimo no podían quedar reducidas a convertirse en un funcionario al servicio de la monarquía. Si ello presuponía de por sí la consecución del favor real, también era preciso incrementar la estima social mediante el ascenso de algunos peldaños en el escalafón nobiliario. Por otro lado, su avanzada visión del mundo de los negocios, su sentido realista y racional de la gestión económica, tampoco tenía por qué ser incompatible con la asunción de los valores propios del grupo social a que pertenecía.

Acumular propiedades y convertirse en señor de vasallos constituía posiblemente la vía más adecuada para empezar a escalar posiciones; obtener las máximas atribuciones jurisdiccionales contribuía a despejar el camino emprendido, pero sólo podía descansarse cuando se había conseguido un título nobiliario de cierta categoría. Aparte de otras consideraciones aducidas páginas atrás, las iniciativas señoriales protagonizadas por D. Jerónimo, las solicitudes de mero y mixto imperio y la obtención final del título de marqués, cobran así una nueva dimensión. En un sistema social jerarquizado y dominado por los valores propios de la nobleza, la integración en el seno de sus capas más cualificadas mediante la adquisición de títulos representaba la fórmula más adecuada para la promoción personal en todos los ámbitos posibles; sin que ello estuviese reñido con una racionalidad económica que sobrepasara la típica actitud rentista y absentista de aquellos elementos menos dinámicos.

Hasta qué punto D. Jerónimo ejemplificaba perfectamente estas personalidades de transición entre dos épocas, pero también entre dos concepciones sobre el cometido social de la nobleza, nos lo revela, además, los argumentos o méritos aducidos para sustentar la solicitud del título de marqués. Hecho que, por otra parte, pone de manifiesto lo fundamental que para la consecución de sus objetivos resultaba el favor real. Concretamente, tres eran los pilares esenciales que habían de respaldar su petición:(204).

a) Los servicios prestados por sus antecesores a la monarquía. Entre ellos, la heróica muerte de su abuelo, caído en plena batalla cuando defendía Guardamar de un ataque pirático, y los servicios ofrecidos por su padre en las cortes de 1585 .

b) Su propia contribución a la defensa militar del Reino, sustentando a su costa durante 6 días 12 compañías de infantería y 4 de caballería, que acudieron a la costa de Guardamar ante la amenaza de 8 navíos enemigos, y armando dos lanchas a tal efecto. Asimismo, levantando una compañía de 100 infantes para Italia en 1634.

c) Su riqueza «en los donativos que ha pedido el Rey a sus vasallos ha acudido a ello dando de su hazienda 1.500 libras y procurando que la Ciudad de Orihuela sirviesse con 2.000 , cuya cobrança facilitó con su crédito y a su exemplo se animaron los demás». Además ofrece ahora 60.000 reales de plata doble. 
Finalmente, significaba su lealtad a la corona durante los 10 años que venía ejerciendo el cargo de lugarteniente del Gobernador.

En definitiva, no estaba sino aludiendo a los tres elementos fundamentales que configuraban y, al propio tiempo, justificaban la valía y el prestigio de la nobleza como grupo social preeminente: las glorias de los antepasados y, por extensión, la sangre; la función militar y política en defensa del estado; y la riqueza.

\section{El destino del patrimonio}

Una vez analizadas las diferentes vías que permitieron al primer marqués de Rafal constituirse como uno de los mayores potentados del Reino, sería conveniente indicar el destino de los bienes que había conseguido acumular. En este sentido, resultan de especial interés las disposiciones contenidas en los sucesivos testamentos y codicilos que a lo largo de su dilatada vida llegaría a otorgar, así como las donaciones realizadas con fines matrimoniales a favor de sus descendientes. Aunque su primer testamento no fuera suscrito hasta 1622, el continuo crecimiento, tanto de su prole como de su fortuna, determinaría la necesidad de ir introduciendo algunas modificaciones a lo largo de los años siguientes, en un intento de ajustar el reparto de su herencia a las nuevas situaciones que iban surgiendo en cada caso. Es por ello que hubiera de otorgar nuevas escrituras en 1626,1634 y $1638^{(20))}$. En 1645 , su esposa y usufructuaria realizaría un nuevo codicilo, rectificando algunas cláusulas anteriores(206).

Pero más que una pormenorizada descripción de cada una de las disposiciones conviene resaltar, en un balance final, las líneas maestras que definen su actitud al respecto y que pueden resumirse del modo que sigue.

En primer lugar, la vinculación de los patrimonios principales a favor de sus dos primogénitos, correspondientes a cada uno de sus matrimonios. D. Nicolás, engendrado por su primera esposa, recibiría el mayorazgo de Benferri -instituido en 1588 por el padre de D. Jerónimo-, integrado por el señorío del mismo nombre, con las mejoras, y los bienes y heredades ya especificados (ver CUADRO 1). Además, le cedía 1.000 libras en obligaciones a que era acreedor.

$\mathrm{Al}$ primogénito de su segundo matrimonio, D. Gaspar, lo nombraba heredero universal del resto de los bienes y títulos que quedasen a su muerte y, como tal, del mayorazgo establecido en 1638, que comprendía el marquesado de Rafal, la baronia de Puebla de Rocamora, unas casas en Orihuela y otros bienes en él incorporados. Todo ello, no obstante, quedaría en usufructo de su esposa mientras viviera. Asimismo, otorgaba a D. Gaspar un hábito de Santiago, obtenido expresamente para el beneficiario en las cortes de $1627^{(207)}$. De este modo, los dominios señoriales, con los títulos anexos, quedarían divididos en dos ramas colaterales, pero no por mucho tiempo. Un siglo más tarde ambos mayorazgos volverían a unificarse bajo un mismo titular, permaneciendo así en lo sucesivo.

El resto de sus hijos varones tampoco habrían de quedar precisamente en la indigencia, pese a recibir, lógicamente, cantidades inferiores. A D. Alonso corresponderían 18.500 libras -equivalentes a la dote aportada por su madre-, libradas en su mayor parte por $\mathrm{D}$. Jerónimo al tiempo de su matrimonio, y un oficio de regidor en la ciudad de Murcia(208). 
Para D. Juan y D. Jaime se destinaron 10.000 libras a cada uno, que recibirían del hereu en el momento de contraer esponsales, en créditos y tierras no vinculadas ${ }^{(209)}$. Pese a ello, no habrían de concurrir las condiciones previstas para segregar tales bienes del núcleo familiar, puesto que $\mathrm{D}$. Jaime quedaría soltero de por vida ${ }^{(210)}$ y D. Juan accedería, antes de su matrimonio, al título y mayorazgo de Rafal, tras fallecer su hermano D. Gaspar sin descendencia(211). De este modo, merced a una posible planificación no exenta de solidaridad, buena parte del patrimonio familiar pudo transmitirse casi en su total integridad.

La parte que sí acabaría por disgregarse, obligando al hereu a su satisfacción, sería la correspondiente a las dotes de sus hijas, a saber: 6.000 libras a D. ${ }^{a}$ María y otras tantas a D. ${ }^{a}$ Inés. Todas ellas libradas efectivamente por D. Gaspar en créditos y bienes muebles, lo que constituye un indicativo del orden de preferencias en relación a las formas de riqueza ${ }^{(212)}$. D. ${ }^{\mathrm{a}}$ Catalina, por su parte, murió soltera ${ }^{(213)}$, mientras que D. ${ }^{a}$ Isabel, D. ${ }^{a}$ Angela y D. ${ }^{a}$ Ana fueron dotadas tempranasmente, en vida de $\mathrm{D}$. Jerónimo, en cantidades inferiores ${ }^{(214)}$.

Pese a la continua sangría que pudo haber supuesto atender los derechos hereditarios -incluidos los alimentos- de tan numerosa descendencia, el núcleo principal del patrimonio familiar pudo finalmente salvarse y garantizar así la continuidad de la fortuna de los sucesivos marqueses de Rafal. A ello contribuyó sobremanera la institución del mayorazgo, orientado precisamente a esta finalidad, pero también la permanencia en manos del titular de una buena parte de los bienes no vinculados y la preferencia por desprenderse de los títulos de la deuda amortizable a corto plazo - equivalente a futuro dinero en efectivo- antes que de cualquier otro tipo de propiedad.

\section{Algunas consideraciones acerca de la «aristocracia alternativa» valenciana}

El caso analizado en este trabajo no ha de ser considerado como un elemento aislado o excepcional en el contexto valenciano de la época. Si así lo pudiera parecer, se debe únicamente a la escasez de estudios realizados sobre el particular y a la unilateralidad de los enfoques con que normalmente han sido abordados.

Generalmente, la caracterización de la nobleza valenciana durante las décadas iniciales del siglo XVII ha sido relacionada con un proceso de creciente endeudamiento - arrastrado desde finales del Quinientos-, con el colapso de sus rentas señoriales - momentáneamente agravado por la expulsión de los moriscos y las dificultades para la repoblación posterior-y con los enormes gastos a que frecuentemente hubieron de hacer frente. Ello ha permitido acuñar expresiones tales como «crisis de la aristocracia» o «bancarrota de los señores» para calificar el balance de su situación económica, lo que en modo alguno resulta discutible en lo que concierne a las grandes familias aristocráticas y a una multitud de nobles que basaban sus ingresos en una renta señorial devaluada. El impacto de los factores adversos mencionados sobre unas formas de gestión económica presididas por actitudes típicamente rentistas e incluso absentistas habría determinado una relativa incapacidad para resolver por sí mismos los problemas y el necesario concurso de la Corona para preservar del desastre al grueso del estamento nobiliario. 
Sin embargo, aún cuando la situación esbozada hubiera estado bastante generalizada - como, efectivamente, hay que admitir - tampoco debe hacerse extensiva a la diversidad de grupos que integraba la nobleza, fundamentalmente en lo que respecta a sus capas inferiores e intermedias. En este sentido habrá que recordar la a firmación de James Casey en su valiosa obra sobre el Seiscientos valenciano: «El Pais Valencià tenia, en efecte, dues aristocràcies el 1609; el 157 senyors y llurs fills més grans, i diversos centenars... de fadristerns o persones ennoblides d'origen més baix, que es fongueren en una ùnica "noblesa urbana" que vivia bàsicament de les anualitats que havien de pagar els senyors». $\mathrm{O}$, más concretamente, «els mercaders rics i els fadristerns dels senyors mateix, exclosos de la terra, constituîren una aristocracia alternativa, una noblesa o patriciat urbà, basat en la possessió dels censals» ${ }^{(215)}$.

Aunque se admita que algunos nobles debieron compartir ambas condiciones y que no constituían grupos antagónicos, tal clasificación presenta, no obstante, una imagen un tanto simplificada acerca de la nobleza y muy especialmente sobre la fisonomía de la «aristocracia alternativa». Si dicho concepto sólo es aplicable a quienes no disponían de patrimonio territorial y limitaban su fuente de recursos a la percepción de intereses censalistas, y se quiere expresar con ello una opción realmente alternativa, habrá que precisar si tales inversiones respondían a una elección personal o si se trataba de una herencia recibida o el resultado de decisiones ajenas. En cualquier caso, la inversión en censales después de 1609 sólo bajo determinados supuestos podia reportar beneficios suficientes como para ser considerada el prototipo de una concepción moderna o actualizada de gestión económica que permitiera escapar a las dificultades de la época. El calificativo de alternativa sólo denotaría, por tanto, la vinculación económica de una parte de la nobleza a una fuente de ingresos definida por el censal y, por ende, su calidad de acreedora, en contraposición a la otra aristocracia agraria y señorial fuertemente endeudada.

En realidad, tal planteamiento es en gran medida la transposición al seno de la propia aristocracia de la dualidad ya expresada por Reglá(216); pero si la ruina de los señores hubieron de soportarla finalmente los sectores acreedores, difícilmente podrían haber protagonizado estos últimos -independientmente de su condición estamental - una vía para remontar satisfactoriamente la crisis - a no ser que recurrieran a procedimientos expeditivos o dispusieran de suficiente fuerza negociadora para resarcirse de las pérdidas.

Con las connotaciones indicadas, el concepto de aristocracia aiternativa, intercambiable en la práctica por el de aristocracia censalista, pierde gran parte de su potencial utilidad explicativa si lo que se pretende es señalar con él el tipo de nobleza que, merced a la puesta en práctica de una concepción distinta sobre su papel económico en la sociedad del momento, conseguiría por sí sola salir indemne de las difíciles coyunturas y aún encumbrar su posición. En ciertos aspectos podría afirmarse incluso que la penuria ajena llegó a constituir uno de los requisitos esenciales para afianzar las bases de sus realizaciones.

Sobre los procedimientos y mecanismos empleados por estos grupos es un fiel exponente el personaje aquí estudiado - por lo que no insistiré de nuevo en ellos-, pero Rocamora no constituyó un caso excepcional. El propio Casey pro- 
porcionó hace unos años algunos ejemplos de empresarios «que acaparaven terres i invertien els seus capitals en l'agricultura» a finales del Quinientos, calificándolos como una «minoria dinàmica, que va saber aprofitarse de les dificultats creixents dels seus compatriotes $)^{(217)}$. Eran éstos D. Pere Franqueza, D. Miquel Fenollet y D. Jaume Rosell, todos ellos procedentes de la pequeña nobleza valenciana y cuya estrategia común consistiría en adquirir tierras, incrementar su dotación de agua de riego y, curiosamente, proceder a la colonización señorial en virtud de la vía abierta por el privilegio alfonsino. De este modo, entre 1597 y 1607 surgían los señoríos de Villafranqueza, Llocnou d'En Fenollet y Benejusser, respectivamente ${ }^{(218)}$.

Lo interesante de estos ejemplos no es tanto el que se recurriera a la enfiteusis, aún de forma parcial o dosificada, como factor de atracción colonizadora, sino la propia estrategia consistente en la transformación de una propiedad plena en núcleo señorial. Quienes optaron por esta vía para la explotación de sus fincas o heredades - pues su reducida extensión permite entenderlas de este modoperseguían, lógicamente, una mayor rentabilidad y revalorización de sus patrimonios pero, en no menor medida, la promoción social y la acumulación de poder que de ello podía derivarse ${ }^{(219)}$.

Casos similares a los precedentes podrían multiplicarse sin necesidad de ampliar excesivamente el marco cronológico de referencia ${ }^{(220)}$. También en la última década del Quinientos y en los años que precedieron a la expulsión de los moriscos se produjeron transformaciones de alquerías en señoríos alfonsinos en el condado de Cocentaina, estudiado por Primitivo Pla. En 1592, el Dr. Micer Esteban Micó de Grecia adquirió la alquería de Rahal Franch, habitada por 5 residentes aparceros, incorporó nuevos moriscos y estableció la tierra a censo enfitéutico, alcanzando muy pronto la jurisdicción alfonsina. En 1607 era el Dr. D. Jerónimo Núñez, recientemente ascendido a la categoría de caballero, quien hacía lo propio en el lugar de Cela - aportado en dote matrimonial por su mujer-invirtiendo considerables sumas con el objeto de reunir las quince familias exigidas por el fuero. Al año siguiente, Francisco March se titulaba señor alfonsino de Benámer, alquería comprada el año anterior y cultivada hasta entonces por unos cuartos $\operatorname{aparceros}^{(221)}$.

Para una redifinición de la aristocracia alternativa también ha de tomarse en consideración, por tanto, la actitud mostrada por elementos de este tipo pero, fundamentalmente, la de aquellos que - como Rocamora - no limitaron su intervención a la mera gestión señorial e intentaron acumular riqueza diversificando el destino de sus inversiones. Si se profundizara suficientemente en las formas de gestión económica y en las fuentes de recursos de la nobleza en general, y no simplemente en la composición de la renta de origen señorial, quizás apareciera más de una sorpresa. No sería infrecuente, por ejemplo, encontrarse con destacadas personalidades participando directamente en la comercialización de productos agrarios, especulando en el mercado usurario, financiando obras de mejora en sus patrimonios; en definitiva, diversificando su campo de inversiones en los sectores que mejores perspectivas ofrecían en cada momento.

Aunque el último objetivo no fuera otro que sortear los malos tiempos y lograr un enriquecimiento personal suficiente para afianzar su posición integrán- 
dose en las capas superiores del estamento, en este recorrido mostraron un criterio más acorde con las prácticas burguesas que con sus congéneres rentistas.

\section{NOTAS}

(1) El propio Lawrence Stone, quien ha investigado a 382 nobles ingleses, reconocía que «las estadísticas nos suministran una dieta seca e insípida, a menos que se la sazone con el vino de la perso. nalidad humana», tras haber afirmado que "la medida estadística es el único medio de deducir un modelo coherente del caos de conductas personales y de descubrir lo que es una muestra típica y lo que se aparta del modelo normal) (La crisis de la aristocracia, 1558-1641. Revista de Occidente, Madrid, 1976, p. 19).

(2) Cit. por J. MILLAN: Rentistas y campesinos, Instituto de Estudios Juan Gil-Albert, Alicante, 1984, p. 97.

(3) Prácticamente, todos los que se han ocupado de uno u otro modo de la citada contienda han destacado la ambigua actitud del IV Marqués de Rafal, a la sazón Gobernador de Orihuela. Con carácter monográfico, A. PARDO Y MANUEL DE VILLENA: El Marqués de Rafal y el levantamiento de Orihuela en la Guerra de Sucesión (1706), Madrid, 1910.

(4) Recientemente, Jesús Millán ha mencionado su actividad colonizadora y su gran propiedad ganadera (Op. cit. p. 97).

(5) Sobre las posibilidades que ofrecen estudios de este tipo, basados en personajes o familias concretos, cf. J. LOPEZ-SALAZAR: «Una empresa agraria capitalista en la Castilla del XVII: La hacienda de D. Gonzalo Muñoz Treviño de Loaisa), Hispania, 148, 1981, pp. 355-407; Eva SERRA I PUIG: «Evolució d'un patrimoni nobiliari català durants els segles XVII i XVIII. El patrimonio nobiliari dels Sentmenat», Recerques, 5, 1975, pp. 33-71; P. de MONTANER y Aine LE-SENNE: «Aproximación al estudio de la formación de la clase noble en Mallorca. El patrimonio de los Formiguera durante el siglo XVII», Trabajos de Geografía, 34, 1977-78, pp. 55-85; J. TORRAS I RIBE: Evolució social i economica d'una familia catalana de l'Antic Règim. Els Padró d'Igualada (í6421862), Fundació Salvador Vives Casajuana, Barcelona, 1976. R. ALIENA MIRALLES: La pluma y la renta. Los Bertran de Benassal (1690-1790), Tesis de licenciatura inédita, leida en la Facultad de Geografia e Historia de la Universidad de Valencia, junio de 1985; M. BASAS FERNANDEZ: «Vida y fortuna de los Gortázar, caballeros ilustrados de Bilbao en el siglo XVIIl», Anuario de Historia Económica y Social, 1, 1968, pp. 403-459; R. MATOSES: "Als voltants dels comportaments de la burguesia rural en els seus origens. El cas de Don Pasqual Castillo i March», Ullal, 2, 1982, pp. 24-31; A. GARCIA SANZ: «Las tribulaciones de un noble castellano en la crisis del Antiguo Régimen: D. Luis Domingo de Contreras y Escobar, V Marqués de Lozoya», V.V.A.A.: Historia económica y pensamiento social, Alianza, Madrid, 1983, pp. 263-281.

(6) Procedentes en su mayor parte del Archivo Histórico de Orihuela (AHO), pero también del Archivo de la Catedral de Orihuela (ACO). Las dificultades para acceder a este último han podido ser subsanadas en buena medida gracias a la colaboración de Javier Sánchez Portas y de los canónigos que han facilitado la consulta.

(7) El acceso a estos fondos no inventariados no hubiera sido posible sin las atenciones dispensadas por D. ${ }^{a}$ M. ${ }^{a}$ Rosario Martín Sanz, a quien he de agradecer su confianza. La documentación referente a los marqueses de Rafal, una vez identificada, ha sido agrupada en un solo legajo para íacilitar su consulta posterior. Cualquier alusión a documentos de esta sección será citada, por tanto, a título provisional.

(8) Las referencias concretas a la documentación utilizada en estos tres archivos mencionados será puntualmente indicada en cada caso.

(9) Barón de FINESTRAT: Nobiliario Alicantino, Instituto de Estudios Alicantinos, Alicante, 1983, pp. 265-267. 
(10) El testamento y vínculo de D. Jaime Rocamora fue otorgado ante Andreu Jordi el 24-III1588. Cuatro días más tarde fallecía el testador. Existe traslado del mismo en AHO: Procesos, leg. Marqués de Rafal.

(11) B. de FINESTRAT: $O p$. cit. p. 267.

(12) La relativa facilidad con que enviudaban y volvían a casar los nobles de la época puede apreciarse mediante una simple ojeada a la obra del Barón de Finestrat. Para el caso inglés, vid. L. STONE: $O p$. cit. pp. 269-270.

(13) Capitulaciones matrimoniales en ACO: Protocolos de Luis Angulo 11-IV-1611.

(14) B. de FINESTRAT: Op. cit., pp. 267-268.

(15) El inventario de sus bienes fue realizado por su viuda el 7-XI-1639. ACO. Protocolos de Ginés Martínez.

(16) Concretamente, la Real Audiencia de Valencia, la Real Cancillería de Granada, el Tribunal de la Inquisición de Murcia, el Supremo Consejo de Aragón en Madrid, etc. A principios de 1623, por ejemplo, se hallaba en esta última ciudad. Archivo Municipal de Orihuela (AMO): Contestador de 1623 , f. 549 .

(17) Nombramientos de procuradores en AHO: Protocolos de Damián León 15-IX-1626, 14 XI-1626, 16-XI-1626, 17-XI-1626, 5-XI-1631.

(18) Como tampoco entre otros muchos nobles y grandes personalidades de la época, por mucho que se haya insistido en potenciar la imagen contraria. Vid. Ch. JAGO: «La crisis de la aristocracia en la Castilla del siglo XVII"), en J. H. ELLIOT ed. Poder y sociedad en la España de los Austrias, Crítica, Barcelona, 1982, pp. 252 y ss.; J. LOPEZ-SALAZAR: Op. cit., p. 356.

(19) Vid. nota 10.

(20) Esta heredad es la misma que, posteriormente, aparece nombrada como Guardalacapa.

(21) D. Gerónimo tuvo un hermano, D. Francisco, quien heredó otros bienes especificados en el vínculo y testamento citado de 1588.

(22) Vid. nota 13. Según su propia declaración, el valor total ascendía a 67.421 libras, pero la suma real de los distintos bienes especificados arroja una cantidad ligeramente superior, que es la que he dado por buena. En cualquier caso, la diferencia -696 libras - no es significativa.

(23) He excluido, lógicamente, otros conceptos como mobiliario, joyas, vestido y enseres de todo tipo - -cuya descripción resultaría excesivamente prolija - por no constar su estimación en dinero.

(24) E. CISCAR: Tierra y señorío en el País Valenciano, Del Cenia al Segura, Valencia, 1977, pp. 114-121; J. CASEY: El regne de Valencia al segle XVII, Curial, Barcelona, 1981, pp. 108-110, 153.

(25) P. BORONAT: Los moriscos españoles y su expulsión, Valencia, 1901, II, p. 613.

(26) D. BERNABE: Tierra y sociedad en el Bajo Segura (1700-1750), C.A.P.A.-Universidad, Alicante, 1981, p. 173.

(27) Sobre la cuestión censalista después de 1609, vid. fundamentalmente J. REGLA: Estudios sobre los moriscos, Ariel, Barcelona, 1974 ( $3 .^{a}$ ed.), pp. 123-141; E. CISCAR: Op. cit., pp. 154-158; J. CASEY: Op. cit., pp. 109-111; y los documentos aportados por P. BORONAT: Op. cit., Il.

(28) Podría aducirse como ejemplo el caso del Colegio de Predicadores de Orihuela (vid. nota 26). Lógicamente, debieron influir otros factores, además de la reducción de los tipos de interés o las crecientes dificultades para cobrar las pensiones. Especialmente los relacionados con la rentabilidad de otras fuentes alternativas. También en Castilla, es posible detectar cierto paralelismo. (Cf. J. FAYARD: Los miembros del Consejo de Castilla (1621-1746), Siglo XXI, Madrid, 1982, pp. 327, 366, 370 .

(29) Las líneas que siguen se basan en el análisis de escrituras de obligaciones y apocas de cancelación recibidas por el notario Damián León -a quien con mayor asiduidad solía acudir D. Jerónimo-y en el inventario de 1639 (vid. nota 15). Dado que en ambos casos sólo a veces se indica el motivo de la constitución, he optado por no entrar en mayores precisiones estadísticas.

(30) Obligaciones-préstamo con expresa mención de esta cláusula en $\mathrm{AHO}$ : Protocolos de Damián León, escrituras de 10-I-1626, 10-XII-1637, 4-VI-1638.

(31) U. GOMEZ ALVAREZ: «Obligaciones y censos: dos instrumentos de endeudamiento po- 
pular en el Principado de Asturias (siglos XVII y XVIII)», La documentación notarial y la Historia, II, Santiago de Compostela, 1984, p. 391. Incide también sobre este aspecto de las obligacionescréditos J. FERREIRO PORTO: "Fuentes para el estudio de las formas del crédito popular" en el Antiguo Régimen: Obligaciones-préstamo, ventas de rentas y ventas de censos", Actas de las I Jornadas de Metodología Aplicada de las Ciencias Históricas, III, Santiago de Compostela, 1975, pp. 763780 . 241.

(32) B. BENNASSAR: Valladolid en el Siglo de Oro, Ayuntamiento de Valladolid, 1983, p.

(33) AHO: Protocolos de Damián León, escrituras de 29-VII-1625, 9-VII-1631.

(34) Ibidem, escrituras de 18-XI-1625, 30-IV-1626, 5-I-1627, 4-VI-1638.

(35) AHO: Procesos, Carpeta pequeña N. ${ }^{\circ} 5$. Obsérvese la justificación moral aducida, fiel reflejo de la postura adoptada por los doctores escolásticos acerca del interés. (Vid. M. GRICEHUTCHINSON: El pensamiento económico en España (1177-1740), Crítica, Barcelona, 1982, espec. pp. 47-80). Jaime Ortiz se obligaba, además, a «portar sertificatoria a sa despessa per la qual conste de fi el que an pogut guañar les dites quantitats en les dites fires de Medina del Campo fins lo dit dia de dos de agost». Pero la operación no acaba ahí. Acto seguido, D. Jerónimo otorgaba en otra escritura distinta "cessio ans de paga" de todas las acciones y derechos que obraban en su poder contra Ortiz, como si la deuda ya hubiera sido saldada. A continuación, mediante otra escritura, éste reconocía no haber efectuado el pago, obligándose a hacerlo en las condiciones estipuladas. El caso es revelador de las artimañas legalistas empleadas en operaciones de crédito semejantes con tal de eludir posibles irregularidades.

(36) En un inventario realizado por el hereu, D. Gaspar, tras la muerte de su madre y usufructaria en 1645 , se contabilizaron un total de 25 obligaciones incobrables por un valor de 1.575 libras, todas ellas del tiempo de su padre. Las razones eran sobre todo la desaparición del deudor - por fallecimiento, huida y cautiverio - sin haber dejado bienes y, en algún caso, insuficiencia de instrumentos legales para obligarle. AHO: Protocolos Juan Liñan, 1645, ff. 811-861.

(37) AHO: Protocolos de Damián León, escritura de 10-VIII-1626.

(38) ibidem, escrituras de 25-VI-1615, 18-I X-1623.

(39) Las 17.800 libras que recoge el CUADRO III por este concepto corresponden a las tres partidas siguientes:

-Pago que efectuó D. Jerónimo por el Marqués de los Vélez en Valencia «de diverses cambis que prengue, que les propietats de aquell pregueren suma de 14.000 lliures», más 2.000 de intereses; total: 16.000 libras.

-1.500 libras, resto de un cambio de 4.000 que dio a la Junta Patrimonial de Elche, con los intereses discurridos.

-3.000 reales que debe la herencia de $\mathrm{D}$. Juan Ferrández de Mesa, por otros tantos «que pago D. Geroni per aquel de un cambi y interessos».

(40) Vid. nota 35 y AHO: Protocolos de Damián León, escritura de 12-X-1626, donde Bertomeu García de Espejo recibe de D. Jerónimo 400 libras «a cambi per tres fires lo interes de les quals quantitats vol se haja de contar conforme lo guany de les fires de Medina del Campo passades les quals tres fires contadores con dit es desde lo primer del present mes en avant promet redimir dit cambi e pagar los interessos que constara haverse guañat en plata doble axi lo principal com dit interessos per a lo qual vol sia lliurat en la forma e manera que semblants deudors que han pres a cambi es hacostumat».

(41) Tal es el caso, por ejemplo, de la siguiente «cédula de cambi»:

«A Ambrosio Piñon, Madrid: 1626 a 16 de noviembre en Alicante, 45.500 rs. vellon. Para el primero de julio del año 1627. Mandara V.M. pagar por esta primera de cambio a Esau del Borgo, noble florentino residente en Madrid arrendador que es de los frutos y rentas de la vacante del Obispado de Origuela quarenta y cinco mil y quinientos reales de vellon que corriere en essa corte los quales hago pagar de orden de Don Geronimo Rocamora, tiniente de Gobernador de Origuela y Sr. de los lugares de Benferri y Rafal por la ultima paga y resta del subarrendamiento de la vacante de dicho Obispado y los mandara. V.M. assentar como se avisa y Xpo. con todos: Don Jayme Talajero menor».

A continuación, D. Jerónimo se obligaba a efectuar dicho pago en el plazo estipulado y, en caso contrario, a satisfacer «plana y mercantilmente al dit don Jaume Talayero sens contradictio alguna juntament ab tots los interessos mercantils cambis y recambis gastos dañs e interessos ques deuran y 
causaran... declarant que li fara dit pagament en Madrid en moneda de vello o en Alacant en moneda corrent del pressent Regne feta reductio de una moneda a laltra conforme stil mercantil». AHO: Protocolos de Damián León, escritura de 18-XI-1626.

(42) Vid. notas 40 y 41.

(43) J. CASEY: Op. cit., p. 111. Vid, también, nota 76.

(44) Vid. fundamentalmente, A. GARCIA SANZ: «EI censal», Boletín de la Sociedad Castellonense de Cultura, XXXVII, 1961.

(45) AHO: Protocolos de Damián León, testamento de 12-I-1626.

(46) J. CASEY: Op. cit., pp. 178 y ss.

(47) J. REGLA: $O p$. cit., pp. 121-141; E. CISCAR: Op. cit., pp. J. CASEY: Op. cit., pp. 109111, 147-176, 178; del mismo autor: "La situación económica de la nobleza valenciana en vísperas de la expulsión de los moriscos», Homenaje al Dr. Juan Reglá, Univ. de Valencia, 1975, pp. 515-526.

(48) ACO: Protocolos de Luis Angulo, escritura de 24-I-1610.

(49) AHO: Procesos, leg. Marqués de Rafal, memorial del Síndico de los regantes, s. a. (hacia 1714).

(50) AHO: Protocolos de Damián León, escritura de 16-XII-1620. Más adelante, al tratar sobre la baronía de La Puebla, se añadirán detalles sobre esta operáción.

(51) Tal era al menos la versión del síndico de Alfeytamí, según memorial citado en nota 49. De hecho, los regantes dejaron de satisfacer las pensiones ya desde 1620 , entablándose innumerables pleitos que habrian de prolongarse hasta bien entrado el siglo XVIII. A la muerte de D. Jerónimo, su viuda afirmaba ser acreedora a todas las pensiones discurridas desde la citada fecha, hallándose pendiente el proceso en la Real Audiencia de Valencia. ACO: Protocolos de Ginés Martínez, inventario de 7-XI-1639.

(52) Archivo del Reino de Valencia (ARV); Procesos de Madrid, S, n. ${ }^{\circ} 367$.

(53) AHO: Protocolos de Damián León, codicilo de 1-IX-1634.

(54) Existen dos versiones sobre dicha cuantia. En julio de 1639 el marqués evaluaba la deuda en 29.000 libras (AMO: Contestador de 1639, f. 114). Cuatro meses más tarde, su viuda, en el inventario citado (vid. nota 15 ) señalaba entre 25.000 y 26.000 .

(55) AMO: Contestador de 1616, ff. 15, 130v-133.

(56) Archivo de la Corona de Aragón (ACA); Consejo de Aragón (CA), leg. 867, 88/2; AMO: Provisiones Reales 1523-1617, ff. 502-505.

(57) AMO: Contestador de 1619, ff. 164v-165.

(58) Ibidem, ff. 161-162.

(59) Ibidem, ff. 162-162v, 164v-166. Otra de las medidas adoptadas consistió en la imposición de una sisa sobre el vino, a satisfacer por el comprador; determinación que acabaría suscitando la firme oposición del cabildo catedralicio. Ibidem, ff. $171 \mathrm{v}-172$.

(60) Ibidem, ff. 13-14. Dicha exención fue concedida el 14-1I-1619 por los jurados (más adelante volveré sobre ello). Por otro lado, la conveniencia de vender el censal fue estudiada y aprobada por el consell el 3-11-1619, mientras que en la siguiente sesión que éste celebrara -el día 18-el asunto ya había sido resuelto. Ibidem, ff. 164-166.

(61) La operación fue suscrita el 21-II-1619, para la próxima feria de marzo del mismo año. AMO: N. ${ }^{\circ} 849.1579-1649$ (sin foliar).

(62) El censal fue cargado por la ciudad el 5-VII-1619. AMO: N. ${ }^{\circ} 2.138,1591-1670$ (s.f.).

(63) La exención temporal de sisas había sido concedida anteriormente a D. Jaime Rosell para los pobladores que, en 1607 , estaba asentando en el señorío alfonsino de nueva creación de Benejúzar (AMO: Contestador de 1607, ff. 91v-92v). Estas concesiones tenían su origen en una determinación del consell de Orihuela, de 28-X-1543, aunque no por ello debía entenderse que había de ser vinculante. De hecho, más adelante, la ciudad protestaria en repetidas ocasiones por la excesiva proliferación de señorios alfonsinos dentro de sus límites jurisdiccionales. Vid., por ejemplo, ACA: CA, leg. 858, 4/23, J. MILLAN. Op. cit., pp. 293-296.

(64) AMO: Clavería de 1623-1624, (s.f.), consignación de 15-II-1622.

(65) En 1623 ambas partes estaban en pleito ante el Consejo de Aragón por el arrendamiento 
del abastecimiento de la carne de Orihuela. D. Jerónimo, a la sazón en Madrid, recriminó encolerizado a uno de los abogados de la ciudad que le acababan de presentar. AMO: Contestador de 1623, f. 549.

(66) Ibidem, f. 549v.

(67) Aunque no he podido localizar el texto de la concordia, hay varias noticias sobre ellas. Entre otras, vid. AHO: Protocolos de Damián León, escritura de 10-I-1626.

(68) AMO: Contestador de 1624, ff. 59-59v.

(69) La disyuntiva en que se encontraba la ciudad era la siguiente: si se pagaba a D. Jerónimo las cantidades estipuladas en la concordia, muchos de los restantes acreedores no podrían cobrar las pensiones anuales, con los consiguientes riesgos de ejecución que ello comportaba. El problema se trató en un consell celebrado el 14-IV-1624, no llegándose en él a ninguna solución (AMO: Contestador de 1624, ff. $325 \mathrm{v}-328$ ). Cinco dias más tarde se determinó imponer nuevas sisas con el fin de recaudar cantidades equivalentes a las que habian de pagarse a D. Jerónimo, comisionando en unos electos del propio consell la decisión sobre los productos a gravar (Ibídem, ff. $330 \mathrm{y}$ ss.). No parece probable, sin embargo, que tal decisión fuese llevada a efecto, debiendo influir sobre ello la desaprobación del Virrey, cuya licencia era preceptiva desde 1568 para este tipo de imposiciones.

(70) AMO: Contestador de 1625, ff. 24-24v; «acte de consert» de 9-II-1625.

(71) Por esas fechas, la ciudad del Segura estaba siendo sometida a una amplia visita de residencia, encomendada en principio al Dr. Luis Ocaña y posteriormente, tras su destitución, al Dr. Guinart.

(72) Así aparece reflejado en los libros de clavería de la ciudad.

(73) AMO: Contestador de 1629, f. 157. Provisión de 26-XI-1629. Los jurados argumentaban la injusticia que podría suponer el que a $\mathrm{D}$. Jerónimo se le presentase una ocasión de compra o negocio y no tuviese con qué pagar, viéndose obligado a cargarse un censal por haber prestado su dinero a la ciudad. Se trataba del tipo de justificación moral ya conocida como «ratione lucri cessantis et damni emergentis». Vid. nota 35.

(74) Ibídem, f. 156v. Los perjuicios que ello podia ocasionar no sólo a los consumidores, sino también a los pequeños y medianos productores de trigo con dificultades para su venta serían fielmente expuestos por uno de los jurados, cuya discrepancia era expresada en los términos siguientes: «...el pendre la Ciutat el forment a cinch reals barcella li sera dañosa a aquella per co que al dia de hui trobara forment la present Ciutat a quatre reals y mig y encara mes barat y es cert que comprant com pot comprar a dits quatre reals y mig los pobres y el comu de la present Ciutat menjarien lo pa molt barat y comprantlo a cinch reals del dit Don Gerony Rocamora es forços haverlo de menjar mes car ademes que el comu de la present Ciutat esta molt necessitado per no haber venut la seda y que es van remediant el uno de vendre quatre cafisos de forment y el altre sis y altres allo que poden y que comprant estos trescent cafisos de Don Gerony sera fer benifet a dit Don Gerony y no al comu de la present Ciutat». Sobre estas prácticas por parte de los administradores del pósito, vid. D. BERNABE: "Oligarquia municipal e intereses agrarios. Orihuela en la coyuntura subsiguiente a la peste de 1648 », Anales de la Universidad de Alicante. Historia Moderna, 1, 1981, pp. 236-240.

(75) Lógicamente, tal actitud provocaría la denuncia por parte del Procurador Patrimonial ante la Real Audiencia de Valencia. ARV: Procesos, $1 .^{\text {a }}$ parte, let. P., N. ${ }^{\circ} 1694$.

(76) La dinámica de las negociaciones hasta la consecución del acuerdo final no estuvo exenta de dificultades. En principio, D. Jerónimo exigía el compromiso formal de la ciudad de liquidar las deudas contraídas mediante su absorción en un censal por su valor total, que iría redimiéndose paulatinamente en lotes de 1.000 libras. La opinión mayoritaria del consell era partidaria, por el contrario, de acudir a la letra de cambio, por valor de 2.000 libras. Sólo la posterior intervención de la Real Audiencia, recordando al consell la superior tasa de interés que este sistema comportaba, obligaría a reconsiderar la decisión. AMO: Contestador de 1632-33, I, ff. 29-29v, 52-56; II, f. 17.

(77) ACA: CA, leg. 587, 44.

(78) AMO: Contestador de 1632-33, II, ff. 28-28v.

(79) AMO: Contestador de 1639, ff. 51-52v. Se trataba de hacer frente a un servicio real.

(80) Ibídem, f. 415. La Real Audiencia, a la vista de las cuentas y documentos presentados, debería decidir si se habían pagado los intereses todos los años y, en tal caso, si habían de descontarse del capital. 
(81) AHO: Protocolos de Damián León, testamento de 12-I-1626.

(82) AMO: Contestador de 1609, ff. 489v, 521.

(83) D. BERNABE: Tierra y sociedad..., pp. 159-60.

(84) Sobre la tendencia creciente del Colegio de Predicadores a invertir en propiedades agrarias y su preponderante papel económico en la época, Ibídem, pp. 155-160.

(85) Los problemas para reactualizar las rentas procedentes del señorio de Redován no debían ser pequeños, si se toma en consideración las siguientes circunstancias:

a) El señorío había estado poblado por moriscos y cristianos viejos en proporciones similares, pero además había gran número de enfiteutas no avecindados en el lugar que también continuaron manteniendo su dominio útil de la tierra después de 1609 .

b) Pocos meses después de la expulsión de los moriscos, los enfiteutas de Redován, incluidos los no avecindados en el lugar, hacían constar ante notario las antiguas condiciones que regulaban su relación con la señoría (AHO: Protocolos de Damián León, escritura de 22-VI-1610.

c) La carta puebla redactada por $\mathrm{D}$. Jerónimo contenía ya una adición de varios capítulos elaborados por los vasallos del lugar, que reflejan una reducción de ciertos derechos que se les pretendía imponer y que hubieron de ser aceptados por aquél (D. BERNABE: Tierra y sociedad..., pp. 221-224).

(86) P. BELLOT: Anales de Orihuela (siglos $X I V$ - $X V$ ), edic. de J. Torres Fontes, Orihuela, 1956, II, p. 182. El manuscrito original es de 1622 .

(87) AMO: Amojonamiento de Callosa, 1582, F. 87v. Declaración del señor de la Granja, D. Juan Rocamora.

(88) En 1550 se mencionan cuatro heredades, con indicación del nombre de sus antiguos dueños, que habían pasado al patrimonio de los Rocamora en la zona regada por la rambla de Benferri. AMO: Contestador de 1550, f. 389v.

(89) AHO: Protocolos de Jaime Liminiana, escritura de 17-XI-1464.

(90) AMO: Amojonamiento de Callosa, 1582. Sentencia dada el 6-X-1496.

(91) Sentencia dada por el Goberndor de Orihuela el 17-III-1569. Ibidem, ff. 287v-291.

(92) En caso contrario habría figurado en los padrones de la contribución general de Orihuela donde solían incluirse, además, otros lugares de difícil caracterización. Vid., por ejemplo, el de 1530 , en AMO: $N .^{\circ} 981$.

(93) Insiste en la presencia de población J. MONTESINOS: Descripción Histórico-Política y geográfica del Ilustre Obispado de la Muy Noble, Muy Leal y siempre fidelísima Ciudad de Orihuela, (manuscrito redactado a finales del siglo XVIII, correspondiente al tomo XII de su Compendio Histórico Oriolano). En la página 843 señala el autor que en 1470 D. Jaime Rocamora fundó una hermita en Benferri «desde cuyo tiempo se cuenta la fundación del lugar, por haberse dado en el principio a abrir cimientos y al establecimiento de algunas casas y barracas». Tal afirmación, probablemente imputable a su amplio conocimiento del manuscrito de Bellot, tampoco sugiere mayores precisiones.

(94) Se trata de los señoríos de jurisdicción civil o, incluso, de ínfima jurisdicción. Ambas categorias han sido estudiadas por Primitivo Pla en su tesis doctoral Conflictos jurisdiccionales en un gran señorio valenciano: el Condado de Cocentaina ante la consolidación del absolutismo, leída en la Facultad de Filosofia y Letras de la Universidad de Alicante en septiembre de 1985, ff. 994-1.036.

(95) De hecho, en una fecha tan tardía como 1578, Mosén Pedro Masquefa reivindicaba la jurisdicción civil sobre Rojales y Mosén Jaime Roca de Togores hacía lo propio sobre su heredad de Daya Vieja, ambas en el término de Orihuela. Aunque no parece que obtuvieran mucho éxito, durante el siglo XVII aún continuarian denominándose señores, al igual que otros propietarios de heredades vecinas que acabarían transformándose posteriormente en señoríos alfonsinos. En otro lugar analizaré más detenidamente esta problemática.

(96) Vid. nota 10.

(97) AMO: Amojonamiento de Callosa, 1582, f. 87v.

(98) Vid. nota 10.

(99) Vid. nota 95.

(100) AHO: Protocolos de Pedro Fernández, escritura de 4-IV-1610.

(101) El contrato de arrendamiento fue otorgado por 8 años y precio de 950 libras anuales. D. 
Jerónimo entregaba dos pares de mulas con sus aparejos de labor, comprometiéndose Lozano a cultivar la tierra a uso y costumbre de buen labrador, pagar el diezmo y abstenerse de sembrar en olivares y morerales. Ibidem.

(102) P. PLA ALBEROLA: «Condiciones de tenencia de la tierra y jurisdicción en el siglo XVI valenciano. Hacia una tipificación de las alquerías moriscas», La propiedad de la tierra en España, Alicante, 1981, pp. 53-63; del mismo: «Acerca de los contratos agrarios de los mudéjares valencianos: los capitols de Catamarnuc», Anales de la Universidad de Alicante. Historia Medieval, 2, 1983, pp. 119-138.

(103) AHO: Protocolos de José Martínez, escritura de 9-XI-1613.

(104) Como parece haber sucedido, por ejemplo, en el caso de los moriscos de la vecina Albatera en las tierras realengas del señor.

(105) ANI): (onte'sudur de 1619, i. 13

(106) Vid. nota 63.

(107) AMO: Contestador de 1619, ff. 13v-14.

(108) AMO: Contestador de 1609, ff. 489v, 521. Se trataba de impedir la salida de vecinos de Orihuela con destino a los señoríos del entorno recientemente despoblados.

(109) Según Bellot, le dio posesión de ella el Gobernador de Orihuela en 1622 . Aunque no especifica que se tratara de la alfonsina, era ésta la única posible. Op. cit. II, p. 182. Vid. nota 111 .

(110) Sobre la existencia de jurados en Benferri, vid. AHO: Protocolos de Damián Lerón, escritura de 2-II-1633.

(111) AHO: Protocolos de Juan León, escritura de 13-V-1631. Según Madoz, «Este pueblo, llamado antiguamente Benyferri, corresponde al señorio del marqués de Rafal, cuyos antecesores establecieron el terreno con el canon de la sesta parte de las cosechas. Tenia el señor territorial jurisdicción alfonsina con los derechos a ella pertenecientes» (P. MADOZ: Diccionario geográficoestadístico-histórico de España y sus posesiones de Ultramar, Madrid, 1846-49, IV, p. 204.

(112) Como ha señalado Jesús Millán, «La distribución en enfiteusis y la fundación de un señorío debió ser la mejor alternativa para explotar extensiones considerables, cuyo arrendamiento habría necesitado grandes capitales», Op. cit., p. 103.

(113) No ha de olvidarse que, siglo y medio más tarde, en momentos en que se recrudecía el clima abolicionista, los gobiernos ilustrados de Carlos III alentarán procesos colonizadores similares. Vid. A. GIL OLCINA: «La propiedad de la tierra en los señorios de jurisdicción alfonsina», Investigaciones Geográficas, 1, 1983, pp. 7-24. Pero tampoco conviene ignorar la importancia del elemento jurisdiccional, aunque con el tiempo llegará a perder buena parte de su contenido efectivo.

(114) AHO: Protocolos de Damián León, testamento de 30-X-1622. Escritura de compra de tierras anexas a Benferri en Ibídem, 9-X-1619.

(115) Vid. J. MILLAN: Op. cit., pp. 293-294.

(116) ACA: Cancillería Real, R. 487, f. 273. Concesión del «merum et mixtum imperium et omnem jurisdictionem civilem et criminalem in loco suo de la Daya» a Gonzalo García.

(117) P. BELLOT: Op. cit., II, p. 160.

(118) AHO: Proceso del síndica del Azud de Alfeytamí contra el señor de la Daya Nueva, E. 3, T. 2, N. ${ }^{\circ} 16, f .20 \mathrm{v}$. «y apres que dit assut se ha tornat a fer de nou se han recreixcut altres cequies que prenen aygua tambe de dit Assut sens perjuhi de la Cequia de Almoradi y la Daya».

(119) Ibídem, ff. 22-25.

(120) Ibidem, ff. 137v-139.

(121) Ibidem, ff. 147v-148.

(122) Ibidem, ff. 185-213.

(123) Ibidem, ff. 684-685.

(124) El citado proceso acaba en 1659. En 1670, cuando la Daya se hallaba casi totalmente despoblada, aún persistian las instancias de los acreedores. ACA: CA, leg. 666, 89.

(125) AHO: Protocolos de Damián León, escritura de 16-XII-1620. Los regantes debian a D. Jerónimo las 10 pensiones atrasadas del censal de 7.000 libras otorgado en 1610 al $16 \%$ de interés, más otras cantidades adelantadas para financiar las acciones judiciales contra el señor de La Daya. El 
total de ambas partidas alcanzaba la cifra de 5.904-1-3 (en libras-sueldos-dineros). Como las 2.010 tahúllas habían sido rematadas en 7.892-19-11, D. Jerónimo quedaba deudor al azud en 1.925-18-8; cantidad destinada a redimir parte del censal de 7.000 libras que, de este modo, reducía su principal a 5.074-1-4.

(126) Vid. nota anterior.

(127) D. Ginés Rabasa de Perellós, barón de Dos Aguas y señor de Benetússer, interesado en la venta ejecutiva de la baronía de La Daya en su integridad, estaba dispuesto a demostrar «que lo comprador de dites dos mil tafulles qui es lo dit sindich de Alfaytami ab tracte presedent ha venut o reconegut aquelles a Don Geroni Rocamora de la Ciutat de Oriola lo qual tingue fet tracte ab lo dit Don Salvador eixecutat de que consentis en la eixecucio offerta y venda de les dites dos mil tafulles sens proclamar ne contradir sino quant molt en alguna cossa de poch momento y li donaria cinch centes liures com ab tot efecte dit Don Salvador les ha hagudes y cobrades del dit Don Geroni com constara per respostes de aquell y per son cas testimonis». AHO: Proceso del síndico..., f. 394.

(128) Ibidem, ff. 684-685v.

(129) Ibídem, ff. 371.

(130) En 1620, el señor de la Daya segó la cebada y amenazó con segar el trigo sembrado por cuenta de la comunidad de regantes, al tiempo que sus vasallos se negaban a dejar las tierras recientemente enajenadas. Ibidem, ff. 239-240, 345-345v.

(131) Ibidem, ff. $441-442 \mathrm{v}$.

(132) AHO: Protocolos de Damián León, apoca de 18-I-1627.

(133) AMO: Contestador de 1624, ff. 59-59v.

(134) J. MONTESINOS: Op. cit. pp. 837. Se trata de una cita textual copiada por Montesinos de «El Cura Anonimo oriolano en su relación manuscrita, numero 19, hecha en el de 1629 para instrucción de su Ilte. Prelado el Sr. Dr. Bernardo Caballero de Paredes».

ACA: CA, leg. 635, 13/26.

(136) En 1646 habia 8 vecinos en La Puebla (P. PEREZ PUCHAL: Geografía de la población valenciana, L'Estel, Valencia, 1978, p. 8).

En 1666, «nou palaus y una barraca de adoves... y dos barraques més de canes y sisca» (AHO: Protocolos de Bertomeu Roig, inventario realizado en septiembre de 1666).

En 1713, 10 vecinos y 12 en 1716 (J. MILLAN: Op. cit. p. 143).

En 1735, 5 contribuyentes y un pobre (J. CAMARENA: Padrón demográfico-económico del reino de Valencia ¿1735?, Anubar, Valencia, 1966, p. 88. п. 26).

(137) ACO: Protocolos de Ginés Martínez, inventario de 7-XI-1639. El inventario realizado en 1666 (vid. nota anterior) volvía a señalar la presencia de cuatro «llauradors quinters que llauren ab bous», indicando sus nombres y el número de bueyes cedidos por el marqués, que alcanzaban ya las 35 cabezas.

En 1735, se decía de los vecinos de la Puebla que «no tienen ni posehen en el Propiedad alguna por ser todo el expresado Lugar y su termino de la Marquesa de Rafal» (J. CAMARENA: Op. cit., p. 88 , n. 26.

A finales del XVIII escribia Montesinos: «Este lugar propiamente no es mas que una famosa heredad... se compone toda la heredad de 25 vecinos arrendadores con varios moços sirvientes) ( $O p$. cit. p. 557).

Por último, también Madoz, a mediados del XIX, insistía en que «este pueblo es propiedad del señor marqués de Rafaly sus vecinos todos arrendatarios» (Op. cit., ).

(138) AHO: Proceso del síndico..., ff. 345-345v.

(139) En realidad, las tierras establecidas en la baronía, hacia 1603, ocupaban sólo una sexta parte aproximadamente del término; más concretamente, 1.275 tahúllas. Ibídem, ff. 402v-403.

(140) Ibidem, ff. $415 \mathrm{v}-422,559 \mathrm{v}-562$.

(141) Ibídem, ff. 292v-293. Tal era la pretensión de D. Ginés Rabasa de Perellós.

(142) Ibídem, f. 393v.

(143) Ibidem, f. $723 v$ y ACA: CA, leg. 876,186 . La donación de La Daya a favor de D. Ramón de Rocafull en ARV: Manament y Empares 1634, L. 5, m. 53, f. 40. El juramento de fidelidad y vasallaje al nuevo señor en Ibídem, L. 5, m. 54, ff. 1-5. 
(144) AMO: Contestador de 1624, ff. 59-59v.

(145) AMO: Contestador de 1597, f. 124. Tales cesiones fueron bastante frecuentes en el siglo XVI y primeros años del XVII, afectando sólo a partidas del campo, alejadas de la ciudad.

(146) Vid. nota 76.

(147) AMO: Contestador de 1632-33, II, ff. 28-28v.

(148) AMO: Contestador de 1640, establiment de 14-III-1633 (se trata de dos hojas sueltas, foliadas con números 27 y 28 , entre los folios 4 y 5 del mencionado Contestador). Las citas referidas a continuación proceden del mismo documento.

(149) Es difícil creer que D. Jerónimo llegara a confiar en algún momento en la colaboración de sus vasallos de La Puebla para la bonificación de estos almarjales a cambio de los correspondientes establecimientos. Quienes no habían tenido oportunidad de acceder al dominio útil de la tierra ya cultivada no iban a empeñar sus recursos en tan arriesgada aventura. Por otra parte, aunque no poseo datos coetáneos, referencias posteriores indican que su aprovechamiento principal era «para el pasto de copiosos ganados, cavallares, y vacunos, de que se abastecia toda la Governación de Orihuela, y mucha parte de este Reyno, y del de Murcia para fiestas reales y todos travajos de que era el cuero copiosisimo, sin impedir a los arrendatarios de La Puebla, la manuntención de algunas porciones de dichos ganados; y de otras mayores de los de serda. Además de la provechosa cosecha de sosa que producía 1.000 libras». AHO: Procesos, leg. Marqués de Rafal. Se refiere a la situación anterior a 1706.

(150) A.11O: Contestador de 1700, f. 112v.

(151) J. MILLAN: Op. cit., p. 185.

(152) AHO: Procesos, leg. Marqueses de Rafal, «Explicación de los títulos de las adquisiciones de tierras de que se compone la Varonia de la Puebla de Rocamora...». 1631 .

(153) Ibídem, consta la escritura de venta en AHO: Protocolos de Damián León, en 4-VII-

(154) Afirmaba Bellot sobre Rafal que «antiguamente era lugar formado con su justicia y tan grande que, cuando el concejo (de Orihuela) a petición del Infante, pidio socorro de gente a los lugares de la huerta, le tacharon a Rafal 30 hombres». (Op. cit. II, p. 182). Por las mismas fechas -1357-, el justicia de Rafal era «tinent lloch» del de Orihuela (I, p. 48).

(155) AHO: Protocolos de Jacobo Montiel, 1583, ff. 129-129v.

(156) AHO: Procesos, leg. Marqueses de Rafal. Se trata de copias del protocolo original, sin que conste el nombre del notario que recibió las escrituras.

(157) AMO: Amojonamiento de Callosa, 1582, f. 175.

(158) ACO; Protocolos de Pedro Fernández de Hita, escritura de 11-1V-1621.

(159) Ibídem.

(160) AHO: Procesos, leg. Marqueses de Rafal.

(161) AHO: Protocolos de Damián León, concordia de 5-I-1626.

(162) ACO: Protocolos de Ginés Martínez, inventario de 7-XI-1634.

(163) AHO: Protocolos de Juan Liñán, establecimientos de 24-I-1643 a 26 enfiteutas.

(164) Aunque en Redován oscilaba entre 4 y 7 sueldos por tahúlla, en Cox y Benejúzar podía alcanzar los 12, a partir de unos mínimos de 4 y 6 respectivamente, según la calidad de la tierra.

(165) ACA: CA, leg. 587, 44. Las sospechas acerca de la tardanza con que procedió a los primeros establecimientos y la posibilidad de que fueran realizados en 1637 ó 1638 se basa en las siguientes circunstancias: Su hijo D. Gaspar afirmaba haberlos recibido el notario Ginés Martínez, del cual únicamente se conservan actualmente los protocolos correspondientes a 1636 y 1639 . Ahora bien, si el volumen de 1639 contiene abundantes escrituras suscritas por D. Jerónimo y, tras su muerte, por su viuda, el de 1636, en cambio, no registra ninguna.

(166) Es difícil saber en qué proporción, al menos hasta 1643, en que llegaría a alcanzar un máximo, con 26 pobladores, que detentarían las dos terceras partes de la antigua heredad en dominio útil.

(167) Vid. nota 163.

(168) Así lo declaraba su viuda en el inventario de 1639, indicando que muchas de dichas causas aún se hallaban inacabadas. 
(169) Hay que destacar que en la actitud observada pudiera haber influido la diferencia que podía representar la percepción del censo en trigo - a razón de un cahíz por cada 20 tahúllas - con respecto al vigente en las nuevas concesiones. Posiblemente, la obligación de pagar en granos obstaculizara la introducción de nuevos cultivos, pero, por lo demás, la diferencia cuantitativa en términos monetarios era escasa. Bastaba con que el trigo pudiera venderse a 16 sueldos por barchilla para igualar el censo de 9 sueldos por tahúlla.

(170) AHO: Protocolos de Juan Liñán, inventario de 1-IX-1645.

(171) ACO: Protocolos de Ginés Martínez, escritura de 11-IX-1639.

(172) AHO: Protocolos de Damián León, codicilio de 1-IX-1634.

(173) Ibidem, escritura de 15-III-1634. El 4-VII-1631 compraba también 400 tahúllas de almarjal en Catral, por 223 libras, sin hacerlas efectivas en dinero por tratarse de liquidación de una deuda (Ibidem).

(174) Así, por ejemplo, figuran como anteriores propietarios de algunas de las parcelas indicadas, D. Joaquín Vich, Ginés Almodover, Francisco Masquefa, Juan Masquefa, Pere Masquefa (Inventario de 1639).

(175) Una parcela de 10 tahúllas fue adquirida por 583 libras (AHO: Protocolos de Damián León, venta de 29-VII-1625) y otra de 13 por 639 libras y 15 sueldos (Ibidem, venta de 1-VII-1635).

(176) Aunque sólo he localizado cuatro entre los protocolos de Damián León, es posible que haya más en los correspondientes a otros notarios.

(177) Referencia a un arrendamiento «de paraula» por un año en AHO: Protocolos de Damián León, escritura de 11-III-1634.

(178) Ibidem, escritura de 23-II-1630.

(179) En 1626 obtenía $D$. Jerónimo el usufructo de 4 tahúllas de moreral durante 4 años, por 80 libras, que pagó en un par de mulas. Ibídem, arrendamiento de 30-IV-1626.

(180) Ibidem, escritura de 5-XI-1631. 1638.

(181) Casos de este tipo en Ibidem, escrituras de 189-XI-1625, 5-I-1627, 10-XII-1637, 4-VI-

(182) Además de los citados en nota anterior, otros ejemplos en Ibídem, escrituras de 23-VII1618, 8-III-1620, 5-X-1626, 9-XI-1626, 5-XII-1626, 30-IV-1626, 5-I-1627, 13-III-1627.

(183) Con expresa indicación, en una parcela de 15 tahúllas y en la heredad de la Puerta de Murcia (inventario de 1639).

(184) AMO: Contestador de 1628, ff. 64-71v. El secuestro fue realizado entre el 2 y el 7 de julio, por lo que constituye un índice bastante aproximado de la cuantía de la cosecha, dada su inmediatez.

(185) Las cantidades correspondientes a los años que faltan no han podido ser calculadas por deficiencias o ausencia de la documentación que ha servido de base a la elaboración del cuadro.

(186) AMO: Contestador de 1625, ff. 145-145v; AHO: Protocolos de Damián León, obligación de 31-I-1626. D. Jerónimo contrataba la venta a un precio y plazo estipulado, con los administradores del pósito. Posteriormente, entraba en relación con carreteros castellanos, quienes le firmaban obligación de entrega a un precio ligeramente inferior.

(187) AHO: Protocolos de Damián León, obligaciones de 18-X-1626, 9-XI-1626, 14-11-1626, entre otras muchas. En cuanto a colectivos, podría mencionarse los jurados de Redován, en nombre del común de vecinos (Ibídem, obligación de 4-II-1608).

(188) AMO: Contestador 1603, f. 36.

(189) Así figuraba en una de las cláusulas expresadas en el contrato de arrendamiento de dicha heredad, suscrito por D. Jerónimo el 25-IV-1618 (AHO: Protocolos de Damián León). Los datos referentes a otras heredades están tomados del Inventario de 1639.

En el manifiesto del vino de 1630, sin embargo, nuestro hombre sólo figura como cosechero de 30 cántaros, producidos en el término de Almoradí -donde se ubicaba la Era Alta. (Vid. A. FELIPO ORTS: «El control de la producción vinícola en el País Valenciano durante el siglo XVII: los manifiestos de 1627-1631", Estudis, 11, Valencia, 1985, p. 72). Probablemente ese año tuviese las otras dos heredades cedidas en arrendamiento -en cuyo caso el manifiesto sería realizado por el arrendatario-, aunque no cabe descartar la posibilidad de ocultación. 
(190) Asi se expresa en el inventario de 1639, precisándose que dicho vino era de los vasallos.

(191) AHO: Protocolos de Damián León, escritura de venta de 5-1-1627.

(191 bis) Ibídem, escrituras de venta y apoca de 20-IX-1626. Curiosamente, en la apoca correspondiente no se hace mención expresa al recibo del dinero pero sí a la entrega real del vino..

(192) AHO: Protocolos de Pedro Fernández, arrendamiento de 4-IV-1610.

(193) AHO: Protocolos de Damián León, escritura de 22-II-1631.

(194) Vid. nota 41.

(195) Por ejemplo, la tutoría de D. ${ }^{\text {a }}$ Ana Molins, AHO: Protocolos de Juan León, escrituras de 29-VIII-1637, 12-II-1639.

(196) AHO: Protocolos de Juan León, obligación de 3-VII-1638. Alquiler de 6 toros para correrlos en la plaza de la villa de Elche.

(197) En 1626, por ejemplo, cedió a medias 50 cerdos y 2 barracos por dos años. D. Jerónimo aportaría la mitad de la cebada que consumieran los lechones que nacieran, repartiéndose por mitad los beneficios de su venta. Al final del período recobraría las madres y los barracos. AHO: Protocolos de Damián León, 14-XI-1626.

(198) El abastecimiento de las carnicerías de Orihuela sería adjudicado a D. Jerónimo en 1625 , $1626,1627,1628,1629,1632,1634,1637$ y otros años anteriores a 1625. En otros municipios del entorno como Callosa, Almoradí y sus propios señorios, la venta de carne también correría algunos años de su cuenta. Uno de los agentes que solían pujar para él era Baltasar García de Soto.

(199) Tras haber obtenido el abastecimiento para 1634, D. Jerónimo llegó a un acuerdo con D) Jaime Talayero, de Alicante, mediante el cual le cedía el arrendamiento con tal de que se le permitiera sacrificar 2.000 cabezas, ofreciendo a cambio las pieles. Poco después se negaría a cumplir el compromiso acordado, entablándose un pleito que acabaría en el Consejo de Aragón (AHO: Procesos, carpeta pequeña $n .^{\circ} 5$ ).

Al día siguiente de habérsele rematado el correspondiente a 1627 y 1628 éste último, voluntario-D. Jerónimo firmaba concordia con D. Francisco Imperial, de Alicante, cediéndole una participación en la provisión de carne a cambio de contribuir en la mitad de los gastos (AHO: Protocolos de Damián León, escritura de 17-VIII-1626).

(200) Así consta en varias obligaciones, apocas y escrituras de venta otorgadas por blanquers y zapateros.

(201) AHO: Proceso del síndico..., f. 631v.

(202) Vid. nota 75.

(203) La denominación exacta de este cargo era la siguiente: «llochtinent de Portantveus de General Governador» (Vid. E. SALVADOR ESTEBAN: «La Gobernación valenciana durante la Edad Moderna. Cuestiones en torno a su singular estructura territorial», Homenaje a Batllori.

(204) ACA: CA, leg. 587, 44

(205) AHO: Protocolos de Damián León, testamentos de 30-X-1622 y de 12-I-1626; codicilio de 1-IX-1634. El definitivo, otorgado el 29-I-1638 ante el notario Ginés Martínez, no se conserva actualmente.

(206) AHO: Protocolos de Juan Liñán, codicilios de 13 y 15-V-1645.

(207) Así lo afirma el manuscrito anónimo citado por Montesinos, aunque no consta que asistiera a dichas cortes. J. MONTESINOS: Op. cit., p. 837; D. DE LARIO: Cortes valencianas de 1626, Valencia, 1973, pp. 18, 218-219, 274.

(208) Testamento de 1622.

(209) Codicilio de 1645.

(210) BARON DE FINESTRAT: Op. cit., p. 268.

(211) AHO: Protocolos de Bertomeu Roig, I-IX-1666 y 29-V-1667.

(212) AHO: Protocolos de Juan Liñán, 9-III-1648.

(213) BARON DE FINESTRAT: Op. cit., p. 267.

(214) D. ${ }^{\text {a }}$ Angela fue dotada con 4.000 libras (AHO: Procesos, carpeta pequeña $\mathrm{n} .^{\circ} 3$, donde se conserva copia de los capítulos matrimoniales, a 25-VI-1615). No he hallado datos sobre las dotes de D. ${ }^{\text {a }}$ Ana y D. ${ }^{a}$ Isabel, pero puesto que ambas casaron con anterioridad a 1622 y el testamento de ese año establecía legados de 4.000 libras para el resto de sus hijas, es de suponer que debió girar en torno a dicha cifra. 
(215) El Regne..., p. 154.

(216) Me refiero a la contraposición campo/ciudad o economía agraria señorial/economía burguesa censalista; inserta en el planteamiento global de Reglá. Vid. su Aproximación a la Història del Pais Valencià, Eliseu Climent, Valencia, 1973, pp. 151-192.

(217) «Irrigació i economia al Pais Valencià. 1589-1689», Primer Congreso de Historia del País Valenciano, III, Valencia, 1976, p. 288.

(218) Ibidem, pp. 823-824, 287-288. Sobre Villafranqueza y su evolución posterior, vid. A. ALBEROLA ROMÀ: Jurisdicción y propiedad de la tierra en Alicante (ss. XVII y XVIII), Alicante, 1984, pp. 451-477. Sobre el Lloc Nou d'En Fenollet, D. ZAFORTEA Y MUSOLES: «Historia de la fundación del Lugar Nuevo de Fenollet y de su señorío», Saitabi, 27, 1948, Valencia, pp. 5-47. Sobre el caso de Benejúser es discutible que se hubiera alcanzado la jurisdicción alfonsina antes de 1611, en que se otorgó carta puebla para su repoblación. Pero en 1607 su fundador afirmaba que «a empres moure un Poble en la heretat nomenada de Beneiuser y en aquell a construit moltes cases y a despes pus de tres milia lliures y a procurat per tots los medios possibles portar pobladors establint les terres de dita heretat a responsió de quatre sous per tafulla». (AMO: Contestador de 1607, f. 91).

(219) D. Pedro Franqueza, cuya ascendente carrera hasta la Secretaría de Estado sería tan fulgurante como su pronta caida en desgracia, obtuvo en 1602 el título de Conde de Villalonga y en 1604 la jurisdicción de mero y mixto imperio sobre Villafranqueza (A. ALBEROLA ROMÁ: Op. cit., pp. 451-459). También D. Jaime Rosell obtuvo en 1628 la jurisdicción gubernatorio nomine sobre Benejuser confirmada a perpetuidad en 1645 (ACA: CA, leg. 891/81; AMO: $N .^{\circ} 1.061$, ff. 13v-17), llegó a desempeñar el cargo de Bayle General de Orihuela y dejó al final de sus días un extenso patrimonio repartido en dos vínculos. Asimismo, los herederos de Fenollet ocuparían el cargo de Bayle y receptor real de Játiva desde 1612 y, más adelante, los de Gobernador de Orihuela y Lugarteniente del de Valencia (D. ZAFORTEA Y MUSOLES: $O p$. cit.).

(220) Las últimas décadas del siglo XVII registran también la promoción de individuos procedentes de la pequeña nobleza, merced a la acumulación de tierras y su colonización señorial y a la participación en negocios diversos. Entre ellos podrían citarse, por ejemplo, los casos de Vaillo de Llanos, Miralles de Imperial, Santacilia y Perpiñán en Elche (Vid. P. RUIZ TORRES: Señores y Propietarios, Inst. Alfonso el Magnánimo, Valencia, 1981, pp. 214-220) o los de Gallego, Molins y Pérez de Sarrió en el Bajo Segura fundadores respectivamente de los señorios alfonsinos de Benijófar, Molins y Formentera.

(221) P. PLA ALBEROLA: Conflictos jurisdiccionales..., . 890-892, 900, 911-915. 